\title{
ÅSA WAHLIN
}

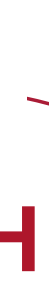

PERIODONTAL HEALTH

AND DISEASE IN TWO

ADULT POPULATIONS

IN SWEDEN
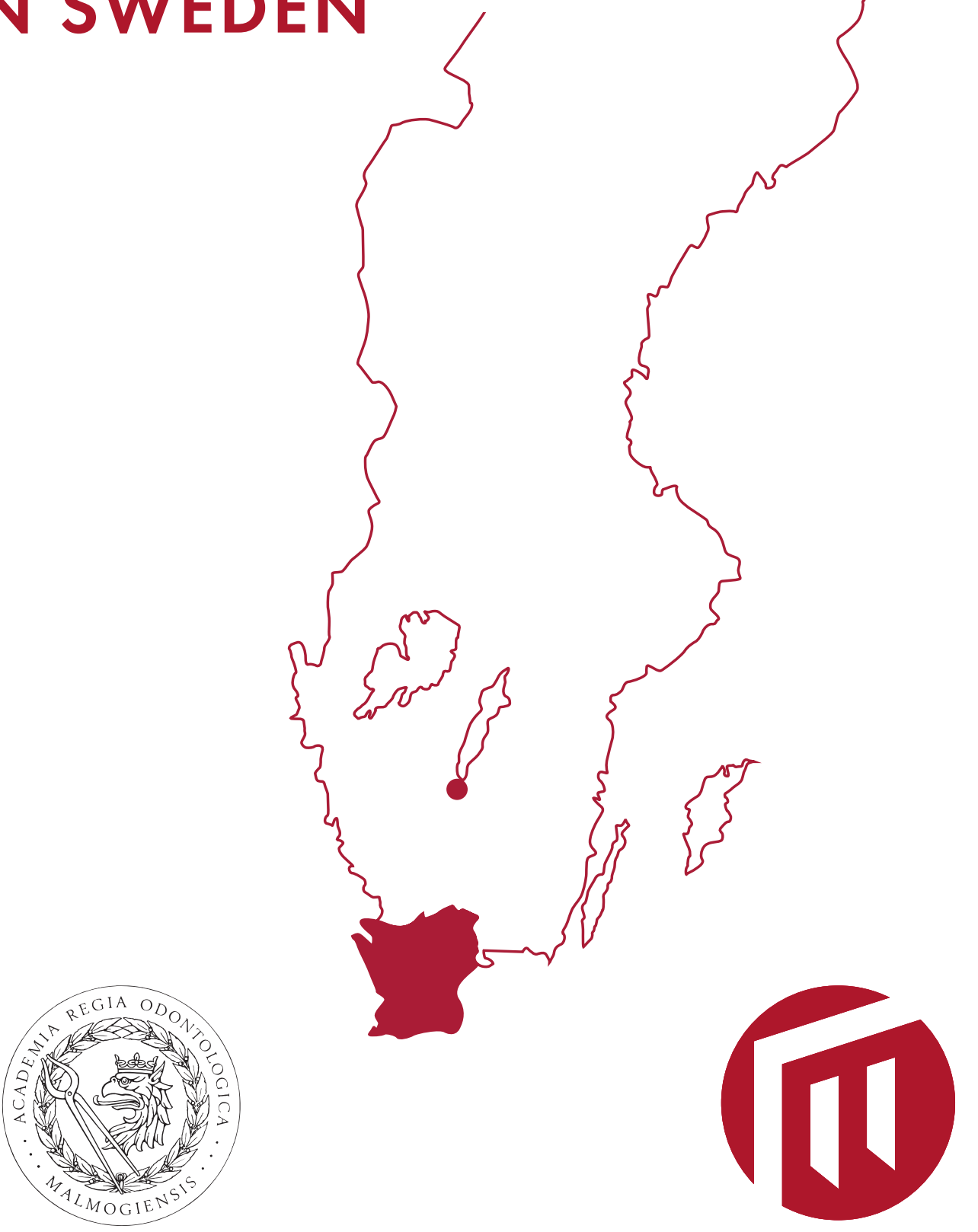

PERIODONTAL HEALTH AND DISEASE IN TWO ADULT POPULATIONS IN SWEDEN 
Malmö University, Faculty of Odontology Doctoral Dissertations 2017

(C) Copyright Åsa Wahlin 2017 ISBN 978-9I-7I04-726-7 (print)

ISBN 978-9I-7I04-727-4 (pdf)

Holmbergs, Malmö 20I7 


\section{ÅSA WAHLIN PERIODONTAL HEALTH AND DISEASE IN TWO ADULT POPULATIONS IN SWEDEN}

Malmö University, 2017

Faculty of Odontology Department of Oral Diagnostics 
Publikationen finns även elektroniskt, se www.mah.se/muep 
To Henrik, Ebba and Didrik 



\section{CONTENTS}

ABBREVIATIONS ............................................ 9

LIST OF PAPERS ............................................ 10

THESIS AT A GLANCE ....................................... 11

ABSTRACT ..................................................... 12

POPULÄRVETENSKAPLIG SAMMANFATTNING .............. 14

INTRODUCTION ............................................ 16

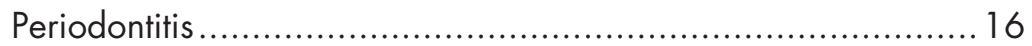

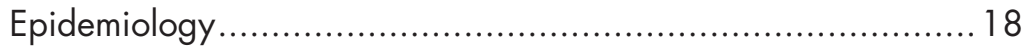

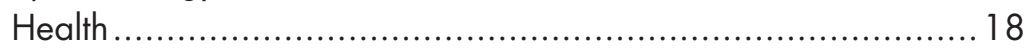

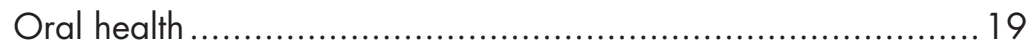

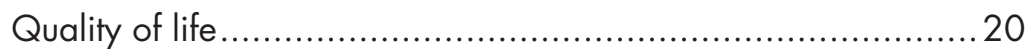

Oral health-related quality of life .........................................20

Periodontitis and oral health-related quality of life................... 21

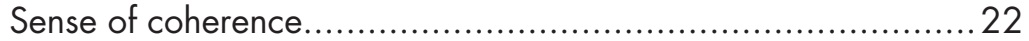

AIMS ....................................................... 25

MATERIAL AND METHODS ................................. 26

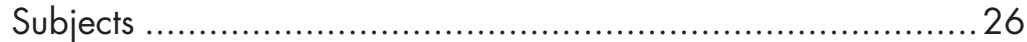

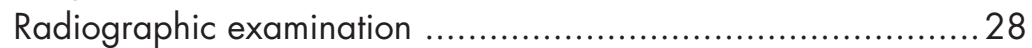

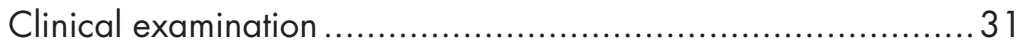

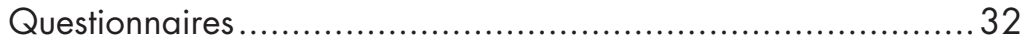

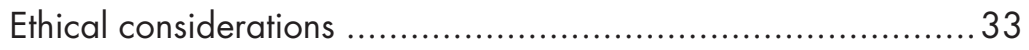

STATISTICAL ANALYSIS ....................................... 35 


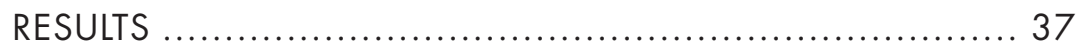

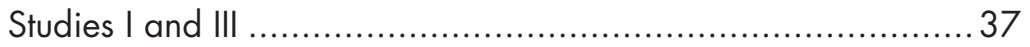

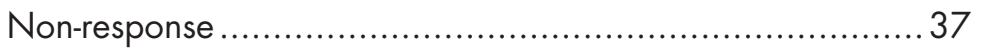

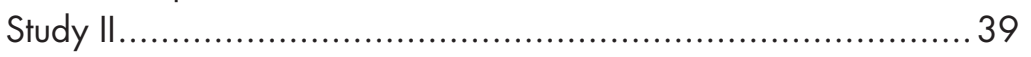

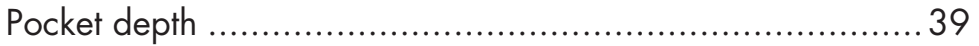

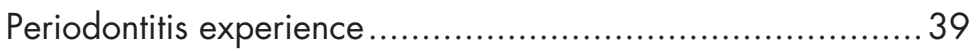

Number of teeth .......................................................... 41

Study III .................................................................... 41

Oral health-related quality of life .................................. 41

Study IV .................................................................... 43

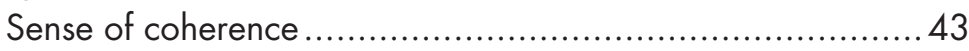

DISCUSSION................................................. 44

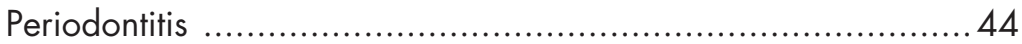

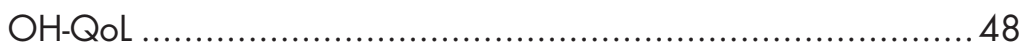

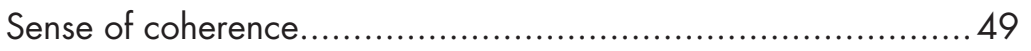

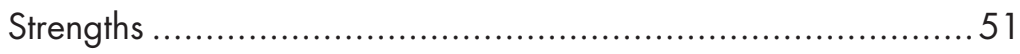

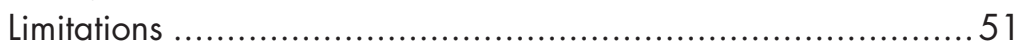

CONCLUSIONS ............................................ 53

FUTURE RESEARCH...................................... 54

ACKNOWLEDGEMENTS ................................... 55

REFERENCES ............................................ 57

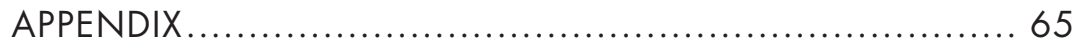

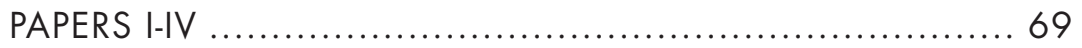




\section{ABBREVIATIONS}

BoP Bleeding on probing

CAL Clinical attachment level

CI Confidence Interval

DALYs Disability-adjusted life-years

GI Gingival inflammation

OECD Organisation for Economic Co-operation and Development

OHIP Oral Health Impact Profile

$\mathrm{OH}-\mathrm{Q}$ oL Oral health-related quality of life

PD Probing pocket depth

QoL Quality of life

SOC Sense of coherence

WHO World Health Organisation 


\section{LIST OF PAPERS}

This thesis is based on the following papers, which will be referred to by their roman numerals as listed below. The published papers are printed with the kind permission of the publishers.

I. WAHLIN $\AA$, JANSSON H, KLINGE B, LUNDEGREN N, ÅKERMAN S, NORDERYD O. Marginal bone loss in the adult population in the county of Skåne, Sweden. Swed Dent J. 2013;37:39-47.

II. WAHLIN Å, PAPIAS A, JANSSON H, NORDERYD O. Periodontal health and disease in individuals aged 20-80 years in Jönköping, Sweden, over 40 years (1973-2013). In manuscript.

III. JANSSON H, WAHLIN A, JOHANSSON V, ÅKERMAN S, LUNDEGREN N, ISBERG P E, NORDERYD O. Impact of periodontal disease experience on oral health-related quality of life. J Periodontol. 2014;85:438-45.

IV. WAHLIN Å, LINDMARK U, NORDERYD O. Individual's sense of coherence does not influence periodontitis severity. Submitted. 


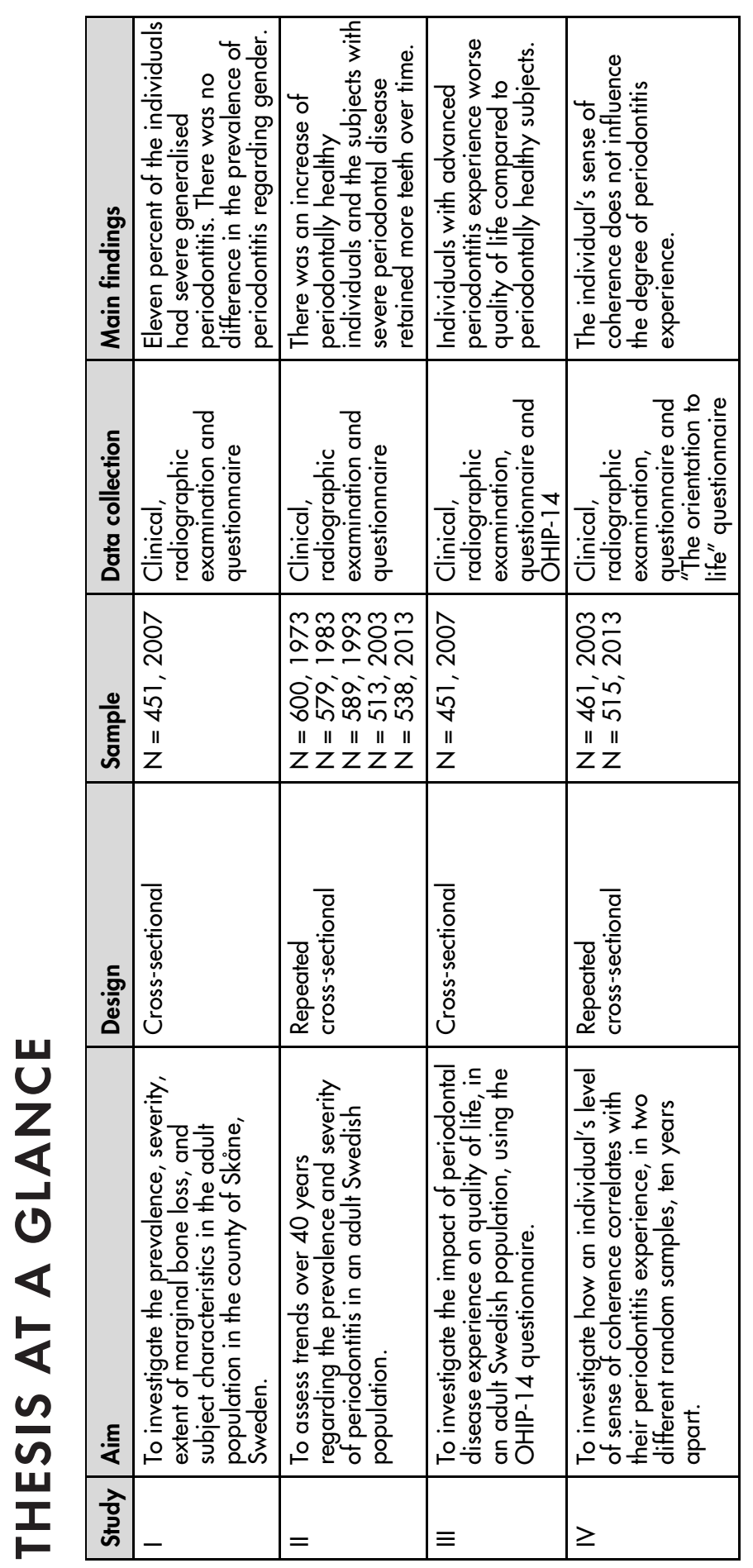




\section{ABSTRACT}

This thesis deals with epidemiological data regarding periodontal disease from two different Swedish populations (Jönköping and Skåne).

\section{Background}

The studies focus on periodontal disease, a disease affecting a large part of the adult population. Periodontitis is a complex inflammatory disease, often chronic, which affects the tissues supporting the teeth - the periodontium. The biofilm that adheres to the hard surfaces of the teeth initiate an inflammation in the supporting tissues. In susceptible individuals, the inflammation may cause the destruction of the periodontium (periodontitis). Individuals with severe periodontitis - between $5-15 \%$ in different populations - show a range of clinical signs and symptoms, such as bleeding gums, mobile and drifting teeth, the loss of interdental papillae, and eventually the loss of teeth. This may affect the function of the dentition and the aesthetic appearance of the individual. Despite this, the disease is often considered to be silent.

\section{Aims}

The overall aim was to study periodontitis prevalence and severity in two Swedish adult populations, and to describe the changes over time. Further aims were to examine the effect of an individual's sense of coherence on periodontitis and to analyse the impact of periodontitis on oral health-related quality of life.

In order to examine this, a series of four different studies were performed with the following specific aims: I) to investigate the 
prevalence, severity, extent of marginal bone loss and subject characteristics in the adult population in the county of Skåne, Sweden; II) to assess trends over 40 years regarding the prevalence and severity of periodontitis in an adult Swedish population; III) to investigate the impact of periodontal disease experience on quality of life, in an adult Swedish population, using the OHIP-14 questionnaire; and finally IV). To investigate how an individual's level of sense of coherence correlates with their periodontitis experience, in two different random samples, ten years apart.

\section{Methods}

One cross-sectional clinical study in Skåne and five cross-sectional clinical studies in Jönköping, repeated every ten years, were performed with random samples of the adult populations. Both study protocols included questionnaires regarding demographic as well as health and oral health-related factors, as well as patient-related outcome measures, such as oral health related quality of life and sense of coherence.

\section{Results}

The prevalence of severe periodontitis experience was eleven percent across the two study populations. There was no difference in periodontitis prevalence according to gender. It was also shown that subjects with severe periodontitis suffered from worse quality of life compared to subjects without periodontitis. Regarding the sense of coherence, no difference could be observed between the different degrees of periodontitis experience.

\section{Conclusion}

The main findings over time were the increase of periodontally healthy individuals and the retention of more teeth among subjects with severe periodontal disease. Also, individuals with advanced periodontitis experience worse quality of life compared to periodontally healthy individuals. 


\section{POPULÄRVETENSKAPLIG SAMMANFATTNING}

Målet för avhandlingen var att studera utbredning och svårighetsgrad av parodontit (inflammationssjukdom vid tandens fäste) och beskriva förändringar över tid. Ytterligare mål var att undersöka om individens känsla av sammanhang (KASAM) kan påverka parodontit samt undersöka hur parodontit påverkar livskvaliteten.

Parodontit är en inflammatorisk sjukdom som skadar vävnaderna som utgör tänders fäste (parodontiet). Det bildas ständigt bakteriebeläggningar (plack) på tänderna som, om de inte avlägsnas, leder till inflammation i det angränsande tandköttet. Utvecklingen av bakteriefloran är en process som pågår på ett likartat sätt hos de allra flesta människor. Hos mottagliga personer kan inflammationen i tandköttet leda till parodontit. Ungefär 5-15\% av alla vuxna har en grav parodontit som orsakar stor förlust av tandfäste och kan innebära att man förlorar tänder. De drabbade har flera kliniska problem, såsom blödande tandkött, tänder som är rörliga och flyttar på sig, förlust av tandkött och i bland förlust av tänder. Detta kan påverka både funktion och utseende hos individen. Parodontit är ofta kronisk och har ett långsamt förlopp, vilket kan förklara varför parodontit många gånger upplevs som symtomfri av både patient och tandvårdspersonal.

När vi studerar sjukdomar undersöker vi ofta faktorer som går att mäta i kliniken och via olika prover. Det är även viktigt att undersöka individrelaterade faktorer som hur individen upplever sjukdomen. Parodontit kräver mycket av den drabbade individen när det gäller munhygien, eventuellt finns det psykologiska faktorer som skulle 
kunna påverka sjukdomsbilden. KASAM handlar om förmåga att hantera stress, att man upplever att man förstår vad som händer, varför det händer och att man kan hantera de olika stressorer man möter i livet.

Fyra olika studier har utförts. De bygger på flera olika tvärsnitts studier med stickprov av slumpvis utvalda vuxna personer. Den ena är en befolkningsundersökning utförd i Skåne 2007. De övriga ingår i en serie tvärsnittsundersökningar, totalt fem stycken i Jönköping som har utförts vart tionde år med start 1973. Gemensamt för alla undersökningarna har varit att kartlägga munhälsan och vårdbehov i befolkningen. Deltagarna i alla undersökningarna har undersökts av tandläkare både kliniskt och med röntgen. Vi har fokuserat på de delar som berör parodontit. Deltagarna har även fyllt i enkäter med frågor om allmänhälsa, munhälsa, tandvårdsvanor och livsstilsfrågor. De fyllde även i frågeformulär som mäter KASAM och livskvalitet relaterat till munhälsa.

Studierna visade att andelen personer utan parodontiterfarenhet har ökat under 40 års tid, 2013 var 60\% av de vuxna parodontalt friska. Förekomsten av grav parodontit var elva procent i Skåne och i Jönköping. Parodontit var lika vanligt hos män som kvinnor. Personer med grava skador på tandfästet uppgav sig ha en sämre livskvalitet jämfört med parodontalt friska eller de med lätta skador. Beträffande om man har stark eller svag KASAM så påverkade det inte parodontitförekomst.

\section{Slutsats}

De viktigaste resultaten i studierna var att andelen parodontalt friska personer har ökat och att individer med grav parodontit har fler tänder i dag jämfört med de tidigare undersökningarna. Dessutom upplever personer med avancerad parodontit sin livskvalitet som sämre jämfört med de som är parodontalt friska. 


\section{INTRODUCTION}

\section{Periodontitis}

Periodontitis is a complex inflammatory disease affecting the tissues supporting the teeth, the periodontium. The biofilm that adheres to the hard surfaces of the teeth can, in susceptible individuals, initiate inflammation that causes the destruction of the periodontium.

The bacterial species associated with periodontal disease are not exogenous pathogens but form part of the normal oral microbiota, even in clinically healthy conditions, although in small numbers $(1,2)$. Socransky et al. (3) described the complexes of bacteria associated with either health or disease, in which the red complex (Porphyromonas gingivalis, Tannerella forsythia and Treponema denticola) was associated with periodontal disease. Recent studies have further increased our knowledge, and describe dysbiosis of the entire microbial structure of the subgingival plaque. Some microorganisms have been shown to have the ability to modify both the microbiome and the host defence $(4,5)$. The consequence of disruption to the microbial-host balance is the transition from health to disease in the periodontal tissues.

In the 1980s, the perspective on periodontitis as a continuum from gingivitis changed. The change came with a shift of focus in the studies. Measures of probing pocket depth (PD), clinical attachment level (CAL) and/or marginal bone loss on radiographs were now reported as frequency distributions and not as means for individuals. Consequently, individuals were grouped according to the proportion of teeth or sites with a given degree of lost attachment, and different disease categories could be identified. 
Hugoson \& Jordan (6) examined the frequency distribution according to the severity of periodontal disease and found that severe loss of periodontal attachment was uncommon before the age of 40, and occurred in at most $8 \%$ of the age groups of 50 years and older. Löe et al. (7) observed male tea labourers in Sri Lanka over a period of 15 years. The population had never been exposed to prevention or treatment of oral diseases. Oral hygiene was absent or insufficient. The researchers identified three different patterns in periodontitis progression. One group with no progression (11\%), a group with moderate progression $(81 \%)$, and a third group who displayed rapid disease progression $(8 \%)$. Additionally, a cross-sectional study in Tanzania (a population with no access to dental care and with high exposure to dental plaque) revealed that, in a subgroup of $31 \%$ of all of the examined individuals, $75 \%$ of teeth with attachment loss of $\geq 7 \mathrm{~mm}$ were found. A severe attachment loss of $\geq 7 \mathrm{~mm}$ was to some extent more prevalent in the older age group compared to the youngest ( $6 \%$ versus zero), but the study confirmed that severe periodontitis affects a minor group of susceptible individuals (8). In Swedish populations, subjects with advanced alveolar bone loss comprise approximately $11 \%$ of all examined adults $(9,10)$. Marginal bone loss of a mild and moderate character was observed in $28 \%$ of the individuals in Jönköping in 2003 and in $33 \%$ of the subjects in Dalarna in 2013, respectively.

Longitudinal studies of periodontitis in industrial countries suggest that the rate of periodontal disease progression in most subjects, and at most sites, is low. A minor group of individuals display more rapid disease progression (11-14). This was confirmed in a prospective longitudinal follow-up that assessed periodontal bone height changes over 17 years in the original 1973 Jönköping study participants $(15,16)$.

Repeated cross-sectional studies have reported trends in the prevalence and distribution of periodontitis. A decrease in the prevalence of periodontitis can be seen in various different populations $(9,10$, 17-22). The improvement can be seen as better oral hygiene (10, 20 ), and more individuals with no marginal bone loss as well as improvements in CAL. (9, 10, 19-22). There is a concomitant increase in the number of teeth retained $(9,10,22)$. Improved 
oral health in the adult population has also resulted in a decreased number of edentulous individuals in Sweden. However, despite these improvements, approximately $10 \%$ of the population continues to suffer from severe periodontal disease $(10,23,24)$.

Globally, severe periodontitis affects $11 \%$ of the adult population (25). It was ranked as the sixth most prevalent disease out of 291 diseases examined in the global burden of disease study (26). Between 1990 and 2010, the burden of both caries and severe periodontitis increased as a result of the ageing population, and population growth.

The World Health Organisation (WHO) measures the burden of a disease in a population compared to a perfectly healthy population in a manner called lost years of healthy life. It is measured as disabilityadjusted life-years (DALYs). The DALYs due to severe periodontitis have increased on a global level. At the same time, the DALYs for severe tooth loss have decreased (26).

\section{Epidemiology}

Epidemiology is defined as "the study of the distribution and determinants of health-related states or events in specified populations, and the application of this study to the control of health problems" (27).

Epidemiological studies examine the factors causing disease as well as the health-promoting factors. The findings from scientific epidemiology are essential for analysing the need for both preventive and treatment interventions in a population. Additionally, they can be used to evaluate the effects of the preventive and treatment interventions provided. Another important use is to analyse trends and plan for future demands to promote public health on a population-level.

\section{Health}

The World Health Organisation (WHO) uses the following definition of health, formulated in 1948: "A state of complete physical, mental and social well-being and not merely the absence of disease or infirmity"(28). 
The WHO definition is set at a very high level. The word "complete" makes it almost impossible to achieve. Huber et al. (29) suggested a new definition: "The ability to adapt and to self-manage" which was intended to render the definition more dynamic. There is no consensus regarding one definition of health. What we define as health and quality of life are constantly being influenced by changes in society, politics, and culture. There are two main health theories: the biostatic and the biopsychosocial perspectives. The traditional model, the biostatic, makes a distinction between the body and the mind; i.e., mind-body dualism. Health and illness are viewed as strictly biological concepts and the individual's experience of them is ignored. The main elements of the theory are biological function and statistical normality, as described by Boorse (30). Nowadays, the focus is more on optimum function in combination with social and psychological well-being. The shift to this more holistic perspective started in the 1970s with Engel's (31) biopsychosocial model, and has further developed into a wider holistic model (32) According to this model, health is defined as a person's ability, given standard circumstances, to realise their vital goals (32).

\section{Oral health}

The mouth plays a central part in our lives. It is essential for drinking, eating, and speaking. Other important functions include general appearance and wordless communication, such as smiling, crying, and kissing. Disease and/or other limitations to these functions have an impact on the individual's physical, social and psychological life, according to Locker (33). Oral health must be considered as an essential part of overall health. Traditionally, there has been a division between oral health and the overall health of an individual. The biomedical model separates the body and mind, but when it comes to oral health, an additional division is made between the mouth and the rest of the body.

Poor oral health has a major impact on public health worldwide. Oral diseases are among the most common chronic diseases (26). They cause suffering and even death. Oral diseases also lead to high costs for both the individual and the society (34). 


\section{Quality of life}

Quality of life (QoL) is a multidimensional concept that has many definitions. Health is an important factor for quality of life, but there are many other important factors, such as living conditions, work, personal development, and social context, as well as cultural factors, values, and spirituality. Like health, the concept of QoL is dynamic, and is constantly being influenced by psychological, societal, and cultural factors (35).

\section{Oral health-related quality of life}

In order to broaden the concept when reporting about health and disease, to encompass more than just clinical parameters, Cohen and Lago (36) argued for the development of complementary "sociodental" indicators. The term "patient-based outcome measures" (PBO) has been proposed to encompass what the individual has to say about their own health (37). Locker (33) developed a conceptual framework for the impact of oral health based on the criteria of the World Health Organisation's international classification of impairments, disabilities and handicaps. This dynamic model aims to explain the relation between clinical conditions and personal and social outcomes. Oral health-QoL $(\mathrm{OH}-\mathrm{QoL})$ can be described as the impact on wellbeing across four aspects: oral function, the psychological aspect, the social aspect, and the experience of pain and discomfort (Figure 1) (38).

Locker's theoretical framework constitutes the basis for a number of the instruments used in dentistry today for measuring OH-QoL. One of the most commonly used is the Oral Health Impact Profile (OHIP) (39). The OHIP was constructed to measure the discomfort, dysfunction, and disability caused by oral disease and oral condition. It has been interpreted as being synonymous with oral health-related quality of life. The Swedish version was found to have good reliability and acceptable validity (40).

We all have a subjective perception of what health and quality of life means to us as individuals. Nevertheless, the multidimensional character of the concepts makes them difficult to measure. 


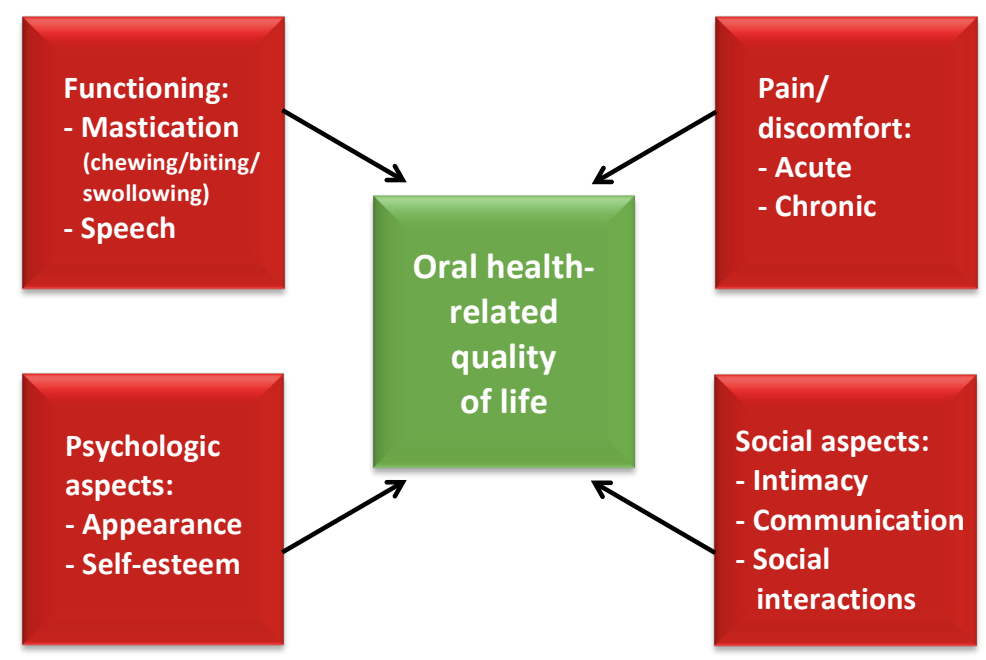

Figure 1. The main components of Oral health-related quality of life. Reproduced with permission from Quintessence Publishing. Inglehart $M R$, Bagramian R. In: Inglehart MR, Bagramian R, editors. Oral Health-Related Quality of Life. Chicago: Quintessence Publishing Co.; 2002. p. 3.

\section{Periodontitis and oral health-related quality of life}

Periodontal disease has commonly been perceived as a silent disease, by clinicians as well as patients, causing no or few symptoms. The slow disease progression of chronical periodontitis probably gives the individual time to adapt, leading to the perception that the disease does not cause symptoms. Actually, the more severe forms of the disease display a range of clinical signs and symptoms, such as bleeding gums, mobile and drifting teeth, the loss of interdental papillae, and eventually the loss of teeth, affecting the function of the dentition and the aesthetic appearance of the individual. Studies on the effect of periodontitis on OH-QoL have led to questions over whether periodontitis can really be regarded as being silent $(41,42)$

When it comes to disease severity, the results are conflicting. Meusel et al. (43) found that periodontal disease severity was inversely correlated to quality of life, but another study reported that gingivitis 
and periodontitis both had comparable negative effects on OH-QoL compared with healthy controls (44). Clinical studies have reported that having more periodontal pockets of $\geq 5 \mathrm{~mm}$ is correlated to worse OH-QoL (45). Cunha-Cruz et al. (41) found no linear correlation between the number of periodontal pockets and $\mathrm{OH}-\mathrm{QoL}$, but having $\mathrm{PD}>5 \mathrm{~mm}$ at more than eight teeth had a negative impact on the $\mathrm{OH}-\mathrm{QoL}$ value.

Both non-surgical and surgical treatment of periodontitis appear to improve the OH-QoL values $(42,46-50)$, although the results are conflicting when it comes to which treatment has the most impact. One study reports that the improvement in Oh-QoL appears to take place after supragingival treatment and before the subgingival treatment is started (42). Makino-Oi et al. (51) found a larger impact on the OH-QoL after periodontal surgery compared with a group who only had non-surgical treatment. Individuals who completed periodontal therapy and attended a maintenance programme reported better OH-QoL compared with individuals referred for periodontal treatment (45). Although the individuals treated for periodontitis reported an improvement in OH-QoL, the scores for this group remained lower when compared with healthy controls in one study (42).

\section{Sense of coherence}

Aaron Antonovsky, a professor in medical sociology, suggested that health and disease should not be treated dichotomously but instead should be viewed as a multidimensional continuum. In 1970, he studied women living in Israel with different ethnic backgrounds. One group was individuals who had survived Nazi concentration camps. Among these women, $29 \%$ had satisfactory mental health as well as physical health (52). He focused on how an individual could live through the concentration camps, then as a refugee, and finally, in a country repeatedly at war, and still be healthy. Based on this research, he described the psychological theory of salutogenesis $(52,53)$. 
All individuals face hardship and stressors in their life. Regardless of the context they live in, this is not something that can be avoided. The concept of sense of coherence (SOC) seeks to explain the relationship between coping with life stressors and maintaining health, i.e., an individual's ability to implement health-promoting behaviour. Sense of coherence is one among many theories and concepts that focus on salutogenesis (54).

SOC is defined as "A global orientation that expresses the extent to which one has a pervasive, enduring though dynamic feeling of confidence that one's internal and external environments are predictable and that there is a probability that things will work out as well as can reasonably be expected" (52). One way to measure SOC is using the "Orientation to life", questionnaire (53). Originally it contained 29 questions and later, a 13-item version was developed (53).

SOC is divided into three components: abilities, comprehensibility, and finally manageability and meaningfulness. Comprehensibility is the ability to see events in life as structured, predictable and understandable. Manageability is the confidence that you have the necessary means, inner and outer, to take control of things or know how to get help. Meaningfulness is an emotional competence, a feeling that the challenges you meet are worth engaging in. Individuals with a strong SOC are considered to have health-promoting behaviours (53). SOC develops during childhood and adolescence and was previously assumed to be stable after the age of 30 . Later research confirmed that SOC stabilises around the age of 30 . But it can change, and it gets stronger with age (55). SOC has been shown to be correlated to quality of life and well-being. Individuals with a strong SOC mostly report having a high quality of life (56).

Research regarding periodontal disease often focuses on aetiology and pathogenesis. A complementary focus on factors in a healthy direction, as well as on an individual's resources - i.e., a salutogenic perspective - may improve existing knowledge about why some individuals stay healthy when seemingly being exposed to the same factors as those who develop periodontitis. 
Studies have reported that adults with a strong SOC have more teeth $(57,58)$, lower plaque scores, and fewer periodontal pockets of $\geq 4 \mathrm{~mm}$ (59). It has also been associated with having positive oral health behaviour (60-64). Individuals with a strong SOC have a more positive attitude to their teeth and perceive their oral health as better (62).

In contrast, other studies found no association between SOC and clinical periodontal health outcomes $(65,66)$. An improved knowledge of individual factors such as SOC may lead to a more holistic view of subjects with periodontal disease and, in the future, the opportunity for more customised prevention and treatment. No studies yet have investigated the effect of the individual's SOC on periodontal disease severity. 


\section{AIMS}

The aim for the thesis was to study periodontitis prevalence and severity in two Swedish adult populations, and to describe the changes in periodontal disease over time. Further aims were to examine the effect of an individual's sense of coherence on periodontitis and to analyse the impact of periodontitis on oral health-related quality of life.

\section{Study I}

To investigate the prevalence, severity, extent of marginal bone loss and subject characteristics in the adult population in the county of Skåne, Sweden.

\section{Study II}

To assess trends over 40 years regarding the prevalence and severity of periodontitis in an adult Swedish population.

\section{Study III}

To investigate the impact of periodontal disease experience on quality of life, in an adult Swedish population, using the OHIP-14 questionnaire.

\section{Study IV}

To investigate how an individual's level of sense of coherence correlates with their periodontitis experience, in two different random samples, ten years apart. 


\section{MATERIAL AND METHODS}

\section{Subjects}

Study I and III

Skane Oral Health Survey

The study was conducted at the Faculty of Odontology, Malmö University, Sweden, with the purpose of evaluating the oral health need and demand for dental care in the region. In 2007, Skåne, had a population of 907,702 individuals aged 20 to 89 years.

The outline and results of the clinical examination, radiographs and questionnaires were previously published by Lundegren et al. in 2012 (67). The study sample was a simple random sample of 1,000 individuals. The sample was drawn from the public register, which includes all people registered as resident in Sweden (SPAR). The sample included subjects aged 20-89 years old who were residents in the county of Skåne, in the southern part of Sweden, in 2007. In total, 451 individuals agreed to participate in the clinical study and were examined both clinically and radiographically. Eight individuals were excluded from this study for the following reasons: two subjects were edentulous; one individual was edentulous but restored with dental implants, radiographs were missing in four subjects, and finally one other individual was excluded due to the poor quality of the radiographs, resulting in an eligible sample of 443 individuals.

The clinical examinations were performed from March 2007 to November 2008 and took place at the Faculty of Odontology at Malmö University and at three Public Dental Service clinics in Skåne, situated in Helsingborg, Kristianstad, and Ystad. The examinations 
were carried out by eight dentists from the Department of Oral Diagnostics at the Faculty of Odontology, Malmö University. The examiners coordinated regarding the diagnostic criteria through comprehensive written instructions and clinical case discussions.

\section{Non-response}

Non-responders were contacted by telephone. One hundred and seventy-five individuals answered the same questionnaire as those attending the clinical examination.

\section{Study II and IV}

\section{The Jönköping oral health studies}

Jönköping is one of the ten largest cities in Sweden. It is an expansive city: since 1973, it has grown from 110,000 inhabitants to 130,000 inhabitants by 2013 . The city is the administrative centre of the region.

A series of cross-sectional studies have been carried out every ten years in the city. The study series includes individuals aged 3, 5, 10, $15,20,30,40,50,60$, and 70 years.

All individuals invited to participate in the study were inhabitants of one of the four parishes of Kristine, Ljungarum, Sofia, or Järstorp, in the city of Jönköping. In 1973, individuals were randomly selected until 100 subjects in each of the groups of ages 20,30,40,50,60, and 70 years had agreed to participate. In 1983, 1993, 2003, and 2013, 130 randomly selected individuals in each of the age groups of 20 , $30,40,50,60,70$, and 80 years were invited to take part. To secure enough participants, an additional sample was invited in 2013. For the age groups 30, 40, and 50 years, additional samples of 40, 40, and 50 respectively were randomly invited.

All subjects received a written personal invitation. Information was given about the purpose of the examination and what it involved, as well as a questionnaire concerning factors about their general and oral health, dental care and dental care habits, as well as other factors such as education. 
The clinical examinations in 2013 were performed by eight dentists from the Department of Paediatric Dentistry, Periodontology/ Endodontics, Prosthodontics, Stomatognathic Physiology, and Oral Medicine at the Institute for Postgraduate Dental Education, and by three general practitioners from the Public Dental Health Service, in Jönköping, Sweden. The examinations were performed between autumn 2013 and autumn 2014.

Adult non-respondents were, if possible, contacted by telephone and asked about their number of teeth, and if they had any type of implant or prosthesis. The reasons individuals selected for the study did not participate were registered. Details regarding the sampling procedure, the number of non-respondents and the reasons for not taking part in the study are given elsewhere (68).

\section{Study II}

All of the examination years $(1973,1983,1993,2003$, and 2013) are included. The 1973 examination includes the age groups 20, 30, 40, 50,60 , and 70 years. The 1983, 1993, 2003, and 2013 examinations include the age groups $20,30,40,50,60,70$, and 80 years.

\section{Study IV}

Includes the examinations from 2003 and 2013, in the age groups of $30,40,50,60,70$, and 80 years.

\section{Radiographic examination}

Study I and III

Digital orthopantomograms and bilateral bitewings were performed on all dentate subjects. The radiographs were analysed regarding marginal bone loss by one calibrated examiner ( $\mathrm{W}$ ), as described by Jansson et al. (69). The observer only had access to numbered anonymised radiographs and no other information regarding the subjects.

The number of teeth was recorded, excluding third molars and root remnants. All measures were conducted using a digital ruler. The teeth were measured mesially and distally, parallel to the long axis 
of the tooth, from the cement-enamel junction to apex and from the most coronal marginal bone level. The site with the most pronounced bone loss represented the tooth as a whole.

\section{Reproducibility of radiographic measurements}

Intra-observer agreement was calculated using Cohen's kappa. The marginal bone level was recalculated in 100 of the participants after random selection. The kappa value was 0.8 and the weighted kappa value was $0.87(70)$.

Classification according to marginal bone loss

The study sample was divided into three different groups.

$\mathrm{No} /$ mild loss of supporting bone $<1 / 3$ of the root length

Local loss of supporting bone $\geq 1 / 3$ root length in $<30 \%$ of the teeth

General loss of supporting bone $\geq 1 / 3$ root length in $\geq 30 \%$ of the teeth.

No/mild was called PD- in study I and BL- in study III.

Local was called PD in study I and BL in study III.

General was called PD+ in study I and BL+ in study III.

\section{Study II and IV}

Due to improved oral health and ethical considerations, the protocol for the radiographic examinations changed during the examination series (68).

For the individuals not examined with full mouth intra-oral radiographs, complementary apical radiographs were taken when deep caries and root-filled teeth were registered.

\section{Reproducibility of radiographic measurements}

Before the start of each examination (1973, 1983, 1993, 2003, 2013), two senior examiners calibrated the other examiners regarding the diagnostic criteria. In 2003, a sample of radiographs from the 1983, 1993, and 2003 examinations were selected from the database by the statistician (10). Two of the observers re-examined the radiographs 
Table 1. Radiographic examinations in the different age groups at each examination year.

\begin{tabular}{|c|c|c|c|}
\hline & $\begin{array}{l}\text { Full mouth intra-oral } \\
\text { examination }\end{array}$ & $\begin{array}{l}\text { Ortho- } \\
\text { pantomogram }\end{array}$ & $\begin{array}{r}\text { Six bite-wing } \\
\text { radiographs -two } \\
\text { each on the left } \\
\text { and right sides } \\
\text { and two in the } \\
\text { frontal region }\end{array}$ \\
\hline 1973 & $20,30,40,50,60,70$ & & \\
\hline 1983 & $20,30,40,50,60,70$ & & \\
\hline 1993 & $40,50,60,70$ & 20,30 & 20,30 \\
\hline 2003 & $50,60,70$ & $20,30,40$ & $20,30,40$ \\
\hline 2013 & 60,70 & $20,30,40,50$ & $20,30,40,50$ \\
\hline
\end{tabular}

that had previously been evaluated by 10 different examiners. Bonelevel measurements were repeated twice and disease classification was also re-done. The inter observer agreement was significant concerning the classification of periodontal disease experience, with Cohen's = 50.70 (70) and bone level (ICC=50.7; 95\% CI, 0.57-0.80).

Classification according to the severity of periodontal disease experience

Modification from Hugoson \& Jordan (6).

Group 1. GI $<20 \%$ and normal alveolar bone height

Group 2. GI $\geq 20 \%$ and normal alveolar bone height

Group 3. Predominantly alveolar bone loss $<1 / 3$ of the root length

Group 4. Predominantly alveolar bone loss between 1/3 and 2/3 of the root length

Group 5. Predominantly alveolar bone loss $>2 / 3$ of the root length, including the presence of angular bony defects and/or furcation defects

Based on these five groups, the study sample was divided into three groups to describe the prevalence of the periodontitis experience in the population. 
No/minor (Groups 1+2) displayed no or minimal periodontal disease experience.

Moderate (Group 3) displayed marginal bone loss not exceeding $1 / 3$ of the length of the root.

Severe (Groups $4+5)$ presented with bone loss of $\geq 1 / 3$ of the root length.

\section{Clinical examination}

Clinical periodontal registrations were recorded at four sites for each tooth: mesial-buccal-distal-lingual at all examinations performed.

Study I and III

Dental plaque: visible plaque was registered. A full mouth score (\%) was calculated.

Bleeding on probing was registered after probing the periodontal pockets (71). A full mouth score (\%) was calculated.

Probing pocket depth (PD) was measured parallel to the tooth with a periodontal probe with $1 \mathrm{~mm}$ grading (Hu-Friedy PCPUNC157). Pockets $\geq 4 \mathrm{~mm}$ were registered.

\section{Study II and IV}

Prevalence of edentulous individuals and number of existing teeth: The number of edentulous individuals and the number of erupted teeth were recorded. Third molars were excluded from the analysis.

Gingival status: Gingival inflammation (GI), or bleeding detected after gentle probing of the gingival tissues, was recorded with scores of 2 and 3, according to Löe \& Silness (72). The percentage of surfaces with inflammation was calculated from the total number of sites.

Probing pocket depth: In 1973, probing pocket depths was measured at all sites, but only the total number of pockets $\geq 4 \mathrm{~mm}$ was reported. In 1983, 1993, 2003, and 2013, the pocket depth $\geq 4 \mathrm{~mm}$ was recorded to the nearest $\mathrm{mm}$ at four sites. 


\section{Questionnaires}

Study I and III

All subjects answered a questionnaire of 58 questions concerning the patient's perception of oral health, oral health care need, pain, use of oral health care and dental materials, as well as questions regarding general health, education etc. (67). The questionnaire included OHIP-14.

\section{Study III}

The OHIP-14 was used to assess the oral health-related quality of life (73). The questionnaire consists of 14 items subdivided into seven domains. The OHIP was constructed to measure the social impacts of oral problems as a total score index, or in seven dimensions: functional limitation, physical pain, psychological discomfort, physical disability, psychological disability, social disability, and handicap (39). The seven conceptual domains are derived from the oral health model (33). The questions were answered on a Likert scale: 0 ("never"), 1 ("hardly ever"), 2 ("occasionally"), 3 ("fairly often"), and 4 ("very often"). A Swedish version of the full-length questionnaire (OHIP-49) has been created and assessed regarding reliability and validity (40). In the present study, the short-form questions from the Swedish translation and the additive method of calculating the scores were used $(35,40)$.

Individuals who did not answer all 14 questions were excluded in the statistical analysis of the total OHIP-14 score. However, in the analysis of each question, all the given answers were included.

\section{Study II and IV}

\section{Questionnaire}

All participants filled out a questionnaire concerning general and oral health, dental care and dental care habits, as well as factors such as education.

\section{Study IV}

The Swedish version of Antonovsky's "Orientation to life" questionnaire was used for measuring the individual's sense of 
coherence (53). The SOC questionnaire, comprising 13 items, consists of three dimensions: comprehensibility (five items), manageability (four items) and meaningfulness (four items). The items were scored on a Likert scale ranging from 1-7. The total sum was used as the score, ranging from 13-91. The questionnaire does not have reference values for what is considered a high or low level for sense of coherence. A high SOC score indicates a strong sense of coherence. The questionnaire has been tested for validity and reliability and has been shown to produce acceptable results in terms of validity, reliability and cross-cultural comparisons (56). Before the analysis, the ranking of the questions number 1, 2, 3, 7 and 10 was reversed.

\section{Ethical considerations}

In all studies, the ethical rules for research as described in the World Medical Association Declaration of Helsinki (74) were followed.

Four different ethical considerations (the information, the consent, the confidentiality and the utility requirement) should be fulfilled in clinical research. Participants in the different study populations all received detailed information about the study and the aims of the study, and were informed that participation was voluntary. They could withdraw from the study at any time, without having to explain why or without any risk that this would have an effect on their future dental care. All clinical data and information from the questionnaires was analysed on a group level. All personal data was replaced by an individual code. Only the principal investigator had access to the unique code key. With this method, the confidentiality requirement was fulfilled. Finally, all data used for the studies had previously been approved by the different regional ethical boards (the utility requirement). All subjects were informed about the opportunity to get information on the results of the study they were included in.

The Medical Ethics Committee of Lund University, Lund, Sweden (ref. no LU 103-2006), approved the study in accordance with the Helsinki Declaration. All study participants gave their signed, informed consent before inclusion in the project. 
The 2003 and 2013 surveys were approved by the Ethical Board at the University of Linköping, Linköping, Sweden (reference number 2003/02-376 and 2012/191-31). 


\section{STATISTICAL ANALYSIS}

\section{Study I}

Descriptive analyses, mean values and standard deviations were calculated based on the subject as the unit. For numerical variables, the comparisons between different periodontitis severity groups were analysed using a General Linear Model. For binary variables, the analyses were logistic regressions, using the likelihood-ratio test. All group comparisons were adjusted for differences in age, gender and smoking habits. A significance level of $5 \%$ was used in all tests (two-tailed).

\section{Study II}

Frequencies and proportion were calculated. For the proportions, 95\% CI was calculated by the bootstrapping technique, which suggests that inference about a population from sample data can be modelled by resampling the sample data and performing inference. This process is repeated a large number of times (typically, 1,000 or 10,000 times) and provides an estimate from which we can answer questions about the dispersion. Mean values with $95 \%$ confidence intervals were calculated on scale level data.

\section{Study III}

For the non-response analysis, cross-tabulations were made concerning study non-participation versus age and gender. A logistic regression analysis was performed with response/nonresponse as the dependent variable. First, age and gender were entered into the model as independent variables. By adding all of the scores from 0 ("never") to 4 ("very often") for each question, the total OHIP-14 score ranges 
from 0 (no problems at all) to 56 (all problems experienced very often). Thus, a lower score indicates a better oral health-related quality of life. Means and standard deviations were calculated for the OHIP-14. Comparisons among groups were made using Pearson's chi-square test for categorical variables, an analysis of variance for numerical variables (one-tailed), and the Tukey test for multiple comparisons. A significance level of $5 \%$ was used in all tests.

\section{Study IV}

Descriptive statistics including frequencies, mean values and $95 \%$ confidence intervals were calculated. Comparisons between groups were made using Pearson's chi-square test for categorical variables, ANOVA for numerical variables, and Bonferroni for multiple comparisons.

Multinomial logistic regression analysis was performed in which the dependent variable was the different levels of periodontal disease experience, and the independent variables were age in years, smoking (expressed as 'presently smoking'), and education to university level. The variables age, gender, education, smoking and SOC value were tested for collinearity.

A significance level of $5 \%$ was used in all tests.

The variable of gender did not have an effect on the regression model and was therefore removed.

All analyses were made using SPSS statistical software (IBM Corporation, Armonk, New York State, USA). Version 20 was used for studies I and III and version 22 for studies II and IV. 


\section{RESULTS}

\section{Studies I and III}

The frequency distribution of the different periodontitis experience groups as well as characteristics regarding gender, age, education, smoking, self-reported cardiovascular disease, number of teeth, PI, BoP and PD are shown in Table 2.

The no/mild group was significantly younger and included significantly more individuals with education to university level compared with the other two groups ( $p \leq 0.001)$.

There were also significant differences among all three severity groups concerning the number of remaining teeth $(26,25$, and 22 ; $p \leq 0.001)$ and the percentage of sites with PD 4 to $5 \mathrm{~mm}(5.4 \%$, $8.5 \%$, and $21.2 \% ; p \leq 0.001)$. Similarly, there was a difference regarding the percentage of individuals with a clinical treatment need between all three groups $(11 \%, 24 \%$, and $53 \%$; $p \leq 0.001)$.

The general group had a significantly higher percentage of sites with $\mathrm{PD} \geq 6 \mathrm{~mm}$ compared with the other two groups $(0.2 \%, 0.6 \%$, and $4.3 \% ; p \leq 0.001)$.

There was no difference regarding periodontitis experience or number of $\mathrm{PD} \geq 6 \mathrm{~mm}$ when comparing gender. However, men demonstrated significantly higher PI $(p \leq 0.001)$ and $\mathrm{BoP}(p=0.018)$ compared with women.

\section{Non-response}

Of the non-responding group, $48 \%$ were women, and $52 \%$ were men. Men in the age group 30 to 39 years $(n=46)$ were the least likely to participate, but no statistical difference could be seen regarding gender when compared with the attenders. Ten percent 


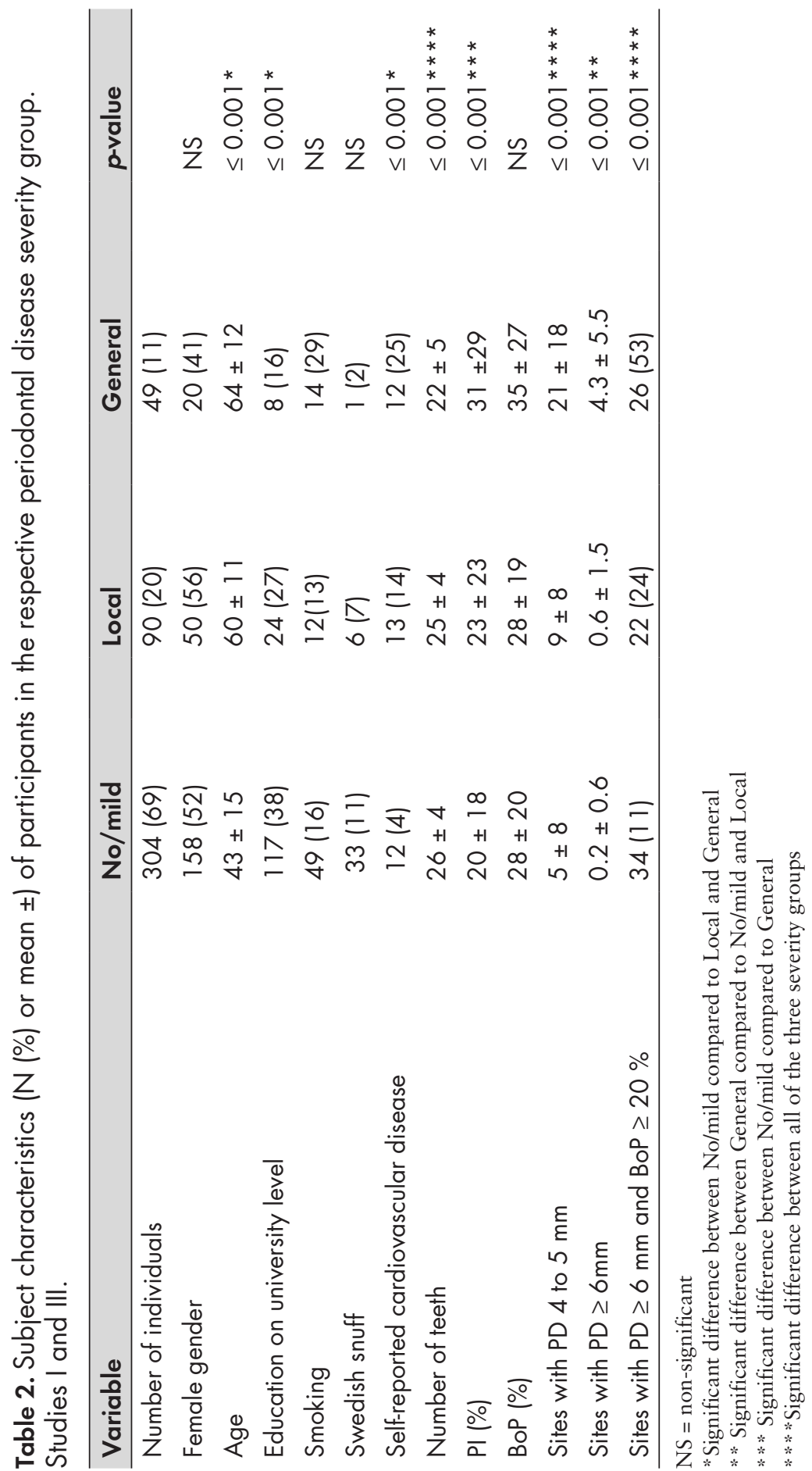


reported being born in a country other than Sweden. Consequently, the number of individuals born outside Sweden was higher than in the group of participants $(p=0.023)$. There were a significant difference concerning age $(p=0.002)$; individuals in the age group 80-89 were less likely to participate. Twenty four percent of the nonattending individuals had a university degree, compared with $34 \%$ of the participants. More individuals in the non-participating group $(11 \%)$ stated that they had a high number of missing teeth ( $>10$ teeth) than in the group of participants $(4 \%)$. There were significantly more smokers in the non-responsive group $(p=0.039)$.

\section{Study II}

\section{Pocket depth}

For subject characteristic se Table 3. The percentage of individuals with $\mathrm{PD} \geq 4 \mathrm{~mm}$ increased with increasing age. There was a decreasing tendency in the percentage of $\mathrm{PD} \geq 6 \mathrm{~mm}$ in the total population from 1983 to 2013. In 50-year-olds, there was a statistically significant decrease in both $\geq 4 \mathrm{~mm}$ and $\geq 6 \mathrm{~mm}$ PD in 2013 compared with 1993. No difference could be seen in the groups no/minimal, moderate and severe regarding the percentage of $\mathrm{PD} \geq 4 \mathrm{~mm}$ or percentage of $\mathrm{PD} \geq 6 \mathrm{~mm}$ over the 40 -year period. Based on $\mathrm{PD} \geq 4 \mathrm{~mm}$ and $\geq 6$ $\mathrm{mm}$, the conditions were unaltered between 2003 and 2013 in all age groups, except for the 20 -year-olds. In this group of subjects, there was a statistically significant increase in the number of $\geq 4 \mathrm{~mm}$ periodontal pockets.

\section{Periodontitis experience}

Between 1983 and 2013, there was a statistically significant increase in the frequency of individuals (20-80-year-olds) with no/minimal periodontitis experience - from 43\% in 1983 to $60 \%$ in 2013. When it comes to age, the increase of individuals with no/minimal periodontitis experience was most pronounced among 40- and 80-year-olds between 2003 and 2013.

The percentage of individuals with moderate periodontitis experience decreased from $41 \%$ in 1983 to $29 \%$ in 2013 . There was no difference in the percentage of individuals classified as having severe periodontitis over the 40 -year period, though, at $16 \%, 15 \%$, $12 \%$ and $11 \%$ in $1983,1993,2003$, or 2013 , respectively. The 


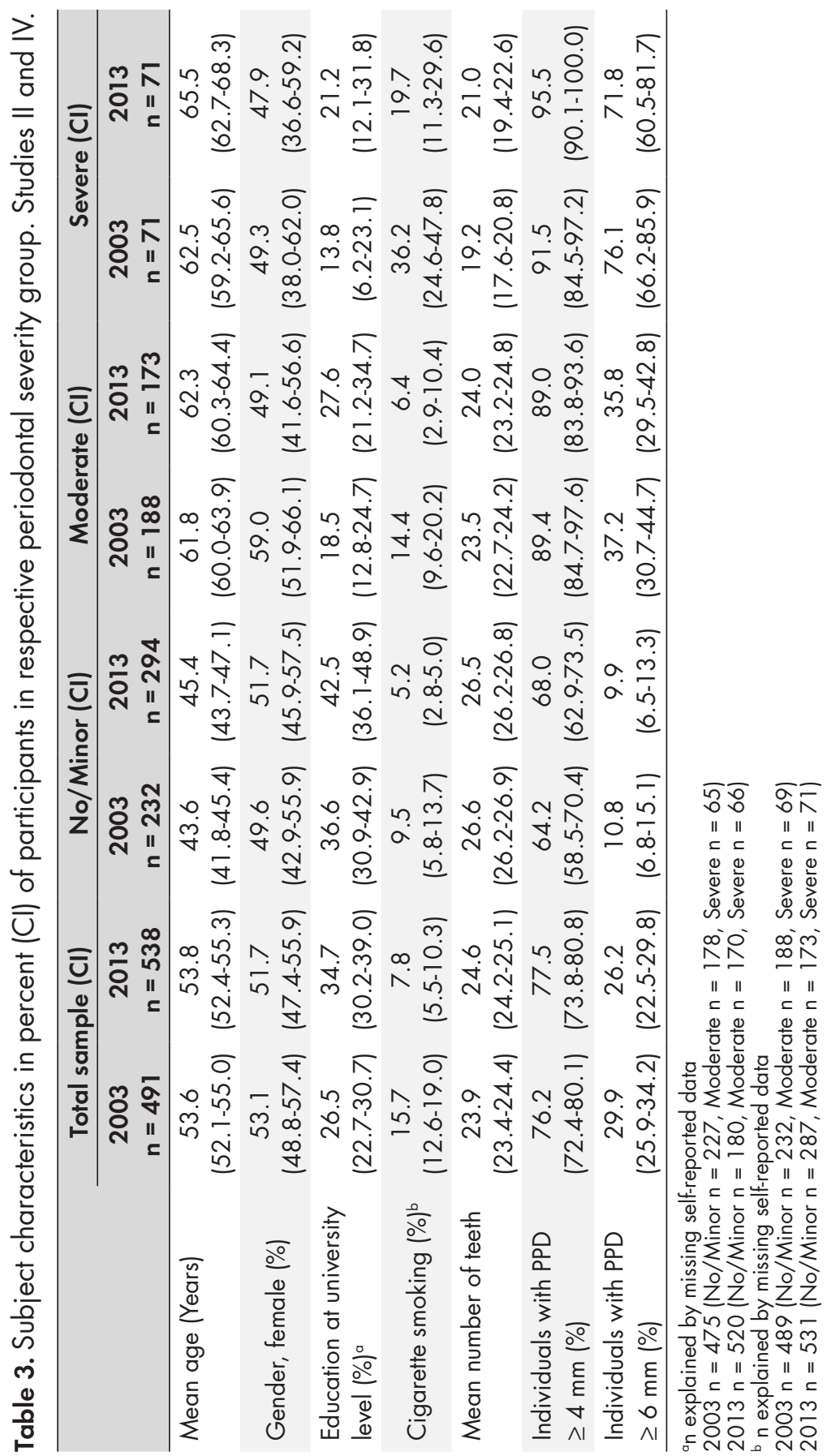


prevalence of individuals in the age group of 20-70-year-olds with severe periodontitis experience was 3\% in 1973.

\section{Number of teeth}

During the 40-year period, the mean number of teeth in the age group of 30-80 years increased at each examination. In 2013, 20-60-yearolds had nearly complete dentitions, and the age groups of 70 and 80 had a mean number of teeth of 22.5 and 21.1 respectively. Between 2003 and 2013, the only disease severity group that showed an increase in the number of teeth was the severe group, with a mean number of teeth of 19.2 in 2003 and 21.0 in 2013.

\section{Study III}

For the study population clinical results, and the non-response rates, see Study I and Table 2.

\section{Oral health-related quality of life}

The no/mild group reported significantly better OH-QoL compared to the severe group $(p \leq 0.001)$. Among no/mild individuals, the mean total OHIP 14 score was 3.9 (SD: 5.4). The corresponding mean values were 3.8 (SD: 5.3) for the local group and 8.5 (SD: $10.4)$ for the general group. There were significant differences in six of the seven conceptual domains: functional limitation $(p=0.017)$, psychological discomfort $(p=0.002)$, physical disability $(p=0.003)$, psychological disability $(p \leq 0.001)$, social disability $(p \leq 0.001)$, and handicap $(p \leq 0.001)$, when comparing the OHIP-14 scores in the different severity groups (Table 4 ).

A multiple regression model was formulated by a forward stepwise analysis, with the total OHIP-14 score as the dependent variable. When including all individuals, the independent variables 1) number of remaining teeth; 2) smoking; and 3) number of individuals with a need for periodontal treatment, expressed as having at least one $\mathrm{PD} \geq 6 \mathrm{~mm}$ and at the same time a full-mouth BOP of $\geq 20 \%$, had a statistically significant influence on the total OHIP-14 score. However, the coefficient of determination for this particular model was only 0.078 . 


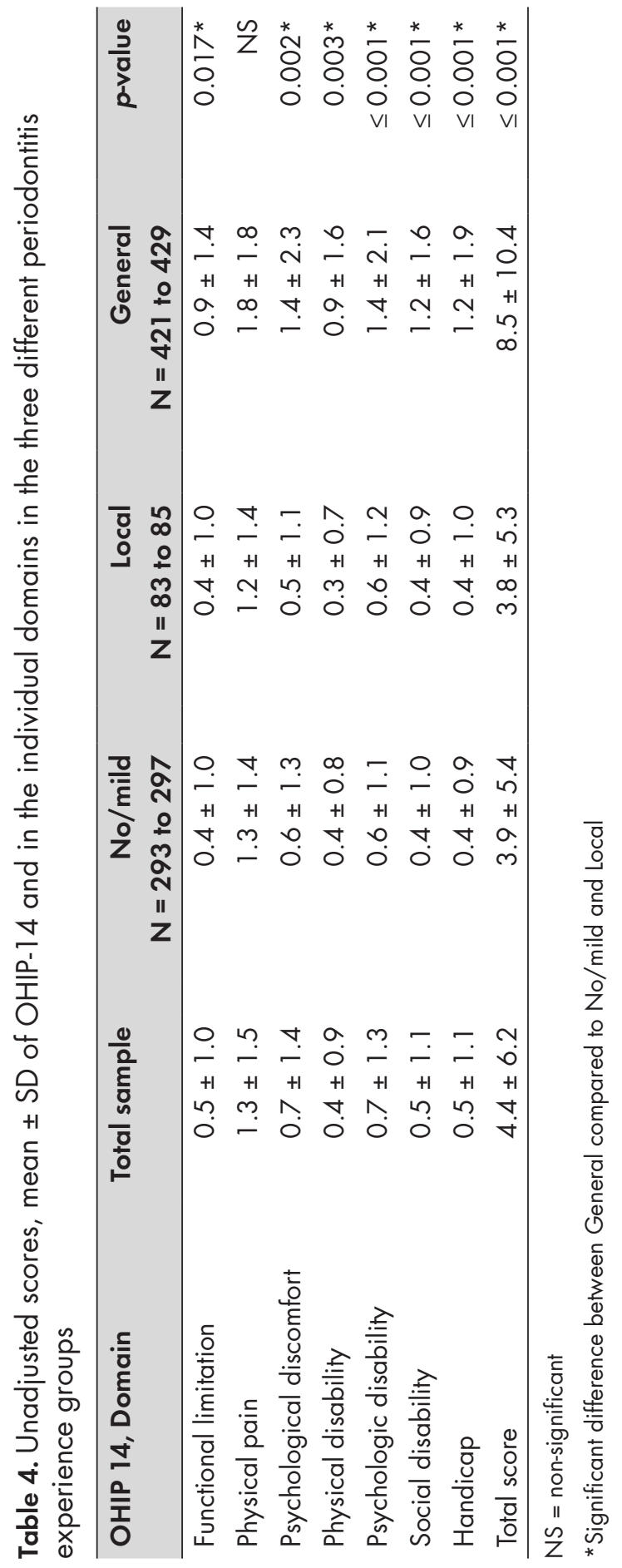




\section{Study IV}

The distribution of subjects according to gender, age, education, smoking habits, number of remaining teeth, and percentage of sites with PD $4-5 \mathrm{~mm}$ and $\mathrm{PD} \geq 6 \mathrm{~mm}$ respectively is shown in Table 3 .

\section{Sense of coherence}

In 2003, the total SOC score in the study population was 70.4 (95\% CI 69.3-71.4). The no/minor group had an SOC score of 71.4 (95\% CI 70.0-72.9). In the moderate group, it was 70.4 (95\% CI 68.6-72.2) and, among individuals in the severe group, the mean SOC score was 68.5 (95\% CI 65.2-71.7). The total SOC score for the study population in 2013 was 70.6 (95\% CI 69.6-71.6). The no/ minor group had an SOC score of 70.5 (95\% CI 69.1-71.9). The moderate group had a score of $71.8(70.0-73.5)$ and, in the severe group, the mean SOC score was $67.6(64.8-70.3)$.

In the multinomial regression analysis, smoking, age, and total SOC score were statistically significantly related to having periodontitis. The strongest overall predictor of periodontitis was smoking, with an odds ratio of having severe periodontitis of 13 in 2003 and 12 in 2013. When it comes to the three domains of comprehensibility, manageability and meaningfulness, no effect on the periodontitis experience could be seen.

Comprehensibility was significantly higher in the total sample and in all three groups according to the periodontitis experience in 2013 compared with 2003. Manageability, on the other hand, was significantly lower in the whole study population, as well as in all three groups, in 2013 compared with 2003. 


\section{DISCUSSION}

\section{Periodontitis}

The prevalence of general periodontitis was $11 \%$ in the population of the county of Skåne in 2007. In the city of Jönköping, the severe periodontitis group represented $11 \%$ of the population in 2013 (Figure 2). There is a difference in the case definition between the study populations, which makes it more difficult to compare the results between the two study populations. The classifications used in both populations are based on the degree of marginal bone loss.

\section{Jönköping}

1983

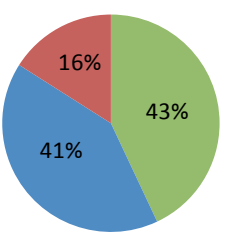

2003

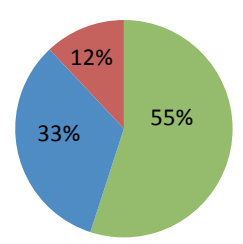

1993

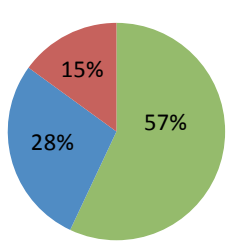

2013

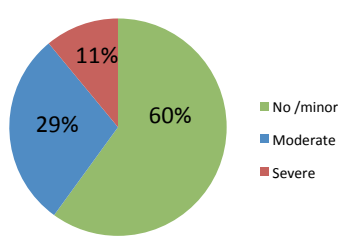

Skåne

2007

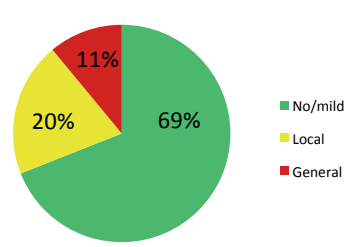

Figure 2. Shows the frequency distributions of individuals with different periodontitis experiences, displaying the two different classifications. 
Individuals belonging to either of the groups can be in need of periodontal treatment or have reduced marginal bone, but heathy clinical conditions. The percentage of individuals with the most advanced loss of supporting bone tissue in both populations is comparable to each other as well as to other studies in industrialised countries. When looking at the Jönköping studies, there seems to be a trend towards a diminished prevalence of severe periodontitis.

Edman et al. (9) reported the prevalence of advanced periodontitis to be $9.2 \%$ in the county of Dalarna in Sweden in 2008. They used a similar classification as the one used in study I and III, which included the measurement of marginal bone loss on radiographs. This is in accordance with the results from both Skåne and Jönköping.

A systematic review and meta-analysis reported the global prevalence of severe periodontitis to be $11.2 \%$ (25). The report included 79 different studies with a number of different case definitions. However, most of them used the Community Periodontal Index. Another common finding was the utilisation of partial recordings. There was a difference in prevalence between the different countries, with a range from $3.6 \%$ to $18.7 \%$. The authors discussed the risk of underestimating the prevalence of severe periodontitis when using partial periodontal recordings. Although the percentage of subjects with severe periodontitis appears to be similar in different populations, the differences in case definition and study design make direct comparisons difficult. Holtfreter et al. (75) compared two different random samples of adults, one group living in New York City and the other living in North East Germany. They used the same methods when comparing the samples and found the prevalence of periodontitis to be higher in Germany, even after controlling for the known risk factors for periodontal disease.

The majority of subjects in both Skåne and Jönköping (2013) had minor experiences of periodontitis. In Jönköping, individuals with no experience of marginal bone loss comprised $60 \%$ of the study population. The group with no or mild periodontitis experience in Skåne was 69\%. 
There was no difference regarding the severity of periodontitis between the female and male genders in either Skåne or in Jönköping. This is in accordance with a cross-sectional Swedish study from Dalarna County (9). However, in studies from other countries men are often reported to have a higher prevalence of periodontitis compared to women $(21,75-78)$.

An explanation for this could be that more women than men in Sweden smoke (79), and smoking is a well-known risk factor for periodontal disease $(80,81)$.

According to the report "Health at Glance 2015", at $<13 \%$, Sweden has one of the lowest percentages of daily smokers among the European countries that belong to the Organisation for Economic Co-operation and Development (OECD), where the average is $23 \%$. However, Sweden and Iceland were the only examined countries where more women than men smoke on a daily basis (79).

In the series of cross-sectional examinations in the city of Jönköping, the percentage of individuals without periodontitis experience increased over time, from $43 \%$ in 1983 to $60 \%$ in 2013. Concomitantly, the prevalence of moderate periodontitis has decreased, while the proportion of individuals in the severe group has more or less remained unchanged.

The periodontal disease classification used cannot detect smaller changes in periodontitis severity within the different groups. Although the group with severe injuries appears to be unchanged, improvements in attachment level cannot be ruled out.

The improved periodontal conditions and the simultaneous increase in the number of teeth in the subjects have both also been shown in another study of the Swedish population (9). The same developments regarding periodontal disease can be seen in other industrialised countries as well, even though they use different case definitions for periodontal disease $(20,22,77)$. Studies from the United States and Germany $(22,77)$ have also shown an increase in the number of teeth, but information regarding the distribution of the number of 
teeth according to disease severity is lacking. Globally, the prevalence of severe periodontitis has been reported to be $11.2 \%$, and between 1990 and 2010 it remained at the same level (25).

Other studies not primarily focusing on periodontal disease have confirmed the increase in the number of teeth in different populations in Sweden as well as in other countries (82-84). Kassebaum et al. (85) also reported a global decline in severe tooth loss (defined as having $<9$ teeth) at both the regional and country levels worldwide.

In Sweden, an explanation for the increase in the number of teeth could be the preventive work performed by dental personnel over the last 50 years. Adults receive a reduction in dental fees for examinations and treatments, both preventive and reparative, through the national dental care subsidy (available at most dentists). It is reasonable to assume that the reduced costs for the patient probably means retention and treatment of teeth, rather than extraction due to financial reasons, is more common.

In the study with tea workers in Sri Lanka, periodontitis was the main reason for tooth loss since caries was almost absent. The group of individuals with rapid disease progression lost the most teeth, and the loss of teeth started when they were about 20 years old. The group of subjects with moderate periodontitis progression also lost teeth, but not to the same extent, and they began losing teeth in their 30s (7). In a comparison between individuals in Norway and Sri Lanka, Löe et al. (86) found more attachment loss in 30-year-olds in Sri Lanka compared with individuals in the same age group in Norway, where oral hygiene was very good. The difference between the two populations can be due to genetic reasons or different levels of oral hygiene and dental care (or both).

Over time, there are signs that can indicate improvements in periodontal status. One indicator is an increase in the number of remaining teeth in the population as a whole. Between 2003 and 2013, an increase in the number of teeth occurred only among individuals belonging to the severe group. Another indicator is a decrease in the number of edentulous individuals. The percentages 
of edentulous individuals (age 40-70) in the Jönköping studies was $16 \%, 12 \%, 8 \%, 1 \%$, and $0.3 \%$ in $1973,1983,1993,2003$, and 2013 respectively (87). Edentulous individuals were excluded when calculating the mean number of teeth and they were also not included in the disease severity groups. The reasons for extracting teeth can vary across different populations. In a Norwegian population, periodontitis was shown to be the main reason for extraction after the age of 45 (88).

A statistically significant reduction in the percentage of individuals with periodontal pockets $\geq 6 \mathrm{~mm}$ was observed in the total sample in 2013 compared with 1983. However, compared with 2003, no change in the presence of periodontal pockets of $\geq 4 \mathrm{~mm}$ or $\geq 6 \mathrm{~mm}$ could be seen. This is in contrast to other studies reporting a decrease in the number of $P D \geq 6 \mathrm{~mm}(20,77)$. One explanation for the unchanged number of periodontal pockets could be that individuals with experience of severe periodontal disease retain more teeth, which might have periodontal pockets.

\section{OH-QoL}

The key finding regarding $\mathrm{OH}-\mathrm{QoL}$ was that subjects with general periodontal destruction in their dentition experience their OH-QoL as worse compared to those either without or with only mild experience of periodontitis. There is more and more support for the idea that periodontal disease has a negative effect on OH-QoL.

Regarding the experience of physical pain due to oral condition, no significant differences could be detected in the present study. This is in contrast to other studies reporting significant differences in the experience of physical pain between individuals with or without periodontal disease $(43,50)$. Saito et al. (50) used a different instrument to measure OH-QoL, which might explain the difference. Another explanation could be the cultural differences between the populations in the studies.

The measure of OH-QoL is difficult; one reason for this is the lack of a clear definition of OH-QoL. Perceived quality of life is influenced by expectations and experiences. One example of this is that 
individuals living with chronic disease report having better $\mathrm{OH}-\mathrm{QoL}$ when compared with healthy individuals, despite living with physical limitations (89). In addition, young adults report having a worse $\mathrm{OH}-\mathrm{Q}$ oL than elderly individuals, regardless of clinical status $(90$, 91).

A limitation with the OHIP-14 is the floor effect; i.e., the majority of scores accumulate at the bottom of the scale (92). The possible total score ranges from 0 to 56, where a low score indicates satisfaction with OH-QoL. All periodontal severity groups in the present study were at the lower range of the scale. The general group had the highest score, of 8.5. This might indicate that periodontitis does not have a major impact on $\mathrm{OH}-\mathrm{Q}$ oL. Subjects suffering from the disease might even perceive their OH-QoL as being good; although the evidence in the literature indicates that severe periodontitis has an adverse impact on $\mathrm{OH}-\mathrm{QoL}$ for the affected individual. Therefore, more studies exploring the reasons why periodontal disease affects $\mathrm{OH}-\mathrm{Q}$ oL are desirable. The effects can be across many different aspects, such as the loss of teeth, the degree of inflammation, drifting teeth, halitosis, aesthetics, and the number and depth of periodontal pockets, among others.

The instruments commonly used for measuring OH-QoL have been criticised for not actually being patient-centred, but rather reflecting the opinion of the expert (the dentist) (93). The statistically significant difference in the score might not be meaningful to the subject. It is important to know the minimally important difference, the smallest difference that is likely to reveal true change, for the OHIP-14 scale and in this case, specifically for individuals with periodontitis (94).

However, although limited in certain aspects, the OHIP-14 has been found to be able to discriminate between groups - for example, between people with and without problems chewing, wearing dentures, and having dry mouths (92).

\section{Sense of coherence}

The mean SOC score in the present study was in accordance with other Swedish population studies $(95,96)$. 
In the multivariate analysis, there was a statistically significant correlation between the SOC score and severe periodontal disease experience, both in 2003 and 2013. However, the odds ratio was almost equal to one, meaning that this statistical significance is not relevant.

The results are comparable to those from a cross-sectional study from Brazil that found no association between the different definitions of gingivitis and periodontitis, plaque index, gingival index, probing depth, clinical attachment level and SOC, but did find a correlation between SOC and perceived periodontal health (66). A recent systematic review of the relationship between SOC and oral health behaviour concluded that a strong SOC is correlated to having positive oral health behaviours, including regular tooth brushing, dental attendance, and less frequent smoking (64). This appears to be in contrast to the results when comparing clinical variables. An explanation for this could be the high level of oral hygiene needed to treat severe periodontitis $(97,98)$. The individual's ability to adapt to this high level of hygiene is essential in order to be able to control the disease. The presence of plaque is a weak predictor of severe periodontitis at the population level (99). This means that on the population level, most individuals do not achieve the level of oral hygiene needed to control the disease in highly sensitive individuals. SOC might have an impact on how well individuals with severe periodontitis are able to adapt to the daily oral hygiene routine that they need for treatment.

The correlation between SOC and psychological health has been documented in the literature, but when it comes to SOC and physical health, the results are more diverse (100).

The total SOC score did not differ between 2003 and 2013, but there was a statistically significant difference in the two dimensions of comprehensibility and manageability. The comprehensibility or ability to understand events increased and at the same time the manageability, the feeling that you have the means to control things, decreased. Another Swedish study reported stability in SOC over 10 years, showing only minor changes (95). The researchers interpreted 
this as being related to societal changes during that time period. This explanation may also be relevant for the results in the present study.

\section{Strengths}

Both the Skåne and Jönköping studies have random cross-sectional study protocols suitable for studying the disease prevalence at a given time point in a population. In Skåne, it was a simple random sample of the adult population living in the county of Skåne in 2007 $(\mathrm{n}=907702)$. A simple random design gives all individuals in the population an equal chance of being selected. In Jönköping, the sample was stratified according to age group to ensure coverage of all adults. The major strength in the Jönköping studies is the study protocol that was repeated, with only minor revisions, every ten years from 1973. Consequently, it is possible to detect changes over time at a population level. Further strengths in both the Skåne and Jönköping studies are the use of the full mouth protocol as well as the periodontal registrations made at four sites in the teeth, excluding the third molars. When using partial periodontal registration protocols, there is a risk of underestimating periodontitis prevalence $(101,102)$ Another strength was the fact that the reading of the radiographs in Study I was done by one observer who had no further information besides the anonymised radiographs. Although the non-response was large, the distribution regarding gender, ethnicity and geographical spread in Skåne in the non-response analysis was comparable to the responders. The prevalence of periodontitis was also in accordance with other studies from Sweden $(9,10)$.

\section{Limitations}

A limitation in Studies I and III was the large group of non-responders $(54 \%)$. The non-responding group who answered the questionnaire included fewer individuals with a university degree and more smokers than the responding group. Both the lower level of education and having a smoking habit are correlated to having severe periodontitis (80). Also, it can be suspected that individuals not responding have worse oral health than individuals taking part in a scientific examination. This means that there is a risk of underestimating the prevalence of periodontitis. Regarding age, there was a difference in the oldest age cohort (80-89 years), which had fewer attenders. The results in this group might therefore be uncertain. 
In the Jönköping studies, the drop-out rate gradually increased between the examinations. The level of drop-outs in the last two examinations was comparable to other studies $(72,76,103)$. A potential risk for bias in the sampling is the addition of individuals in 2013. There is also a risk of underestimating the periodontitis prevalence and overestimating the number of teeth, and in the worst case, overestimating improvements over time, due to selection bias.

To enable a comparison between different epidemiological studies regarding periodontitis, it has been proposed that all studies include registration of clinical attachment $(\mathrm{CAL})$ as a measure for disease severity $(104,105)$. In both Skåne and Jönköping, the disease severity was assessed on radiographs and not as CAL, and this limits the possibilities for comparison with other epidemiological studies. To improve this, CAL should be considered for inclusion in the Jönköping study protocols in the future. 


\section{CONCLUSIONS}

The majority of individuals in both populations (Jönköping and Skåne) had healthy periodontal conditions or a mild form of periodontitis. Eleven percent had severe generalised periodontitis.

There was no difference in the prevalence of periodontitis regarding gender in either of the two examined Swedish populations.

The proportion of individuals in Jönköping without periodontitis experience increased in the population during the study period.

There was a significant increase in the number of teeth in the population over time.

The only group showing an improvement in the number of teeth between 2003 and 2013 was individuals with severe periodontitis.

Individuals with generalised marginal bone loss experienced worse oral health-related quality of life compared with individuals without or with only mild forms of marginal bone loss.

An individual's sense of coherence does not influence the degree of periodontitis experience, but smoking was strongly correlated to severe periodontal disease experience.

The main findings over time were the increase of periodontally healthy individuals and the retention of more teeth among subjects with severe periodontal disease. Also, individuals with advanced periodontitis experience worse quality of life compared to periodontally healthy individuals. 


\section{FUTURE RESEARCH}

In order to further improve periodontal health, new methods for diagnosing periodontitis and methods for identifying individuals susceptible to periodontitis need to be developed and evaluated. Additionally, techniques for accurately determining the effect of periodontal disease on $\mathrm{OH}-\mathrm{QoL}$ are lacking and there is a need to develop instruments specifically designed for this purpose and to implement the use of such instruments in clinical practice.

Another important aspect that requires further research is better knowledge of psychological factors that can contribute to successful treatment outcomes and, consequently, the development of more individualised treatments. 


\section{ACKNOWLEDGEMENTS}

I would like to express my sincere gratitude to all the people who have helped and supported me throughout my research.

A special mention goes to:

Associate Professor Ola Norderyd, my main supervisor, for all your support and friendship. For sharing your knowledge and also for giving me the opportunity to do the research.

Professor Sigvard Åkerman, co-supervisor, for your support and interesting discussions.

Professor Björn Klinge, co-supervisor, for your support.

Associate professor Henrik Jansson, co-author, for your support, cheering on and giving constructive feedback.

Apostolos Papias, co-author, for your support and encouragement and also for reading and giving constructive feedback of the manuscripts.

Nina Lundegren, $\mathrm{PhD}$, co-author, for your support.

Ulrika Lindmark, PhD, co-author, for your help and support and for introducing me to the field of sense of coherence.

Christina Diogo Löfgren, $\mathrm{PhD}$, for your warm support and friendship, and for reading manuscripts and constructive feedback as well as practical guidance.

Shariel Sayardoust for your friendship, for being positive and giving me a lot of energy and support. 
Bengt Götrick, Head of the department of Oral Diagnostics, Faculty of Odontology Malmö University, and the rest of the staff. For making me feel welcome at the department.

Bo Rolander, $\mathrm{PhD}$, for help with the statistics as well as cheering me on.

Helén Jansson for your invaluable help with the layout.

Christina Stenervik for your support and friendship.

Gunilla Leander and Monica Hammar for helping me out mostly by changing my schedule with a short notice. Also for always cheering me on and being supportive.

Per-Erik Isberg, co-author, and for statistical support.

Veronica Johansson, $\mathrm{PhD}$, co-author, for your support.

Brandon Washburn for your kind help with language editing (Although not in this section...)

My colleagues and friends at the Institute for Postgraduate Dental Education in Jönköping, Sweden for cheering me on and making it fun to be at work.

All persons involved in the gathering of clinical data both in Skåne and in Jönköping.

Henrik, Ebba and Didrik for your love and support. I love you!

For the rest of my family and friends for love and friendship!

The following financial support is gratefully acknowledged:

The Public Dental Health Service and Futurum Academy for Health and Care, Region Jönköping County, Sweden

Faculty of Odontology, Malmö University, Malmö, Sweden

The Public Dental Health Service, Region Skåne, Sweden. 


\section{REFERENCES}

1. Socransky SS, Haffajee AD. Dental biofilms: difficult therapeutic targets. Periodontol 2000. 2002;28:12-55.

2. Marsh PD, Head DA, Devine DA. Ecological approaches to oral biofilms: control without killing. Caries Res. 2015;49 Suppl 1:46-54.

3. Socransky SS, Haffajee AD, Cugini MA, Smith C, Kent RL, Jr. Microbial complexes in subgingival plaque. J Clin Periodontol. 1998;25(2):134-44.

4. Darveau RP. Periodontitis: a polymicrobial disruption of host homeostasis. Nat Rew Microbiol. 2010;8(7):481-90.

5. Hajishengallis G. Immunomicrobial pathogenesis of periodontitis: keystones, pathobionts, and host response. Trends Immunol. 2014;35(1):3-11.

6. Hugoson A, Jordan T. Frequency distribution of individuals aged 20-70 years according to severity of periodontal disease. Community Dent Oral Epidemiol. 1982;10(4):187-92.

7. Loe H, Anerud A, Boysen H, Morrison E. Natural history of periodontal disease in man. Rapid, moderate and no loss of attachment in Sri Lankan laborers 14 to 46 years of age. J Clin Periodontol. 1986;13(5):431-45.

8. Baelum V, Fejerskov O, Karring T. Oral hygiene, gingivitis and periodontal breakdown in adult Tanzanians. J Periodontal Res. 1986;21(3):221-32.

9. Edman K, Ohrn K, Holmlund A, Nordstrom B, Hedin M, Hellberg D. Comparison of oral status in an adult population 35-75 year of age in the county of Dalarna, Sweden in 1983 and 2008. Swed Dent J. 2012;36(2):61-70.

10. Hugoson A, Sjodin B, Norderyd O. Trends over 30 years, 1973-2003, in the prevalence and severity of periodontal disease. J Clin Periodontol. 2008;35(5):405-14. 
11. Lindhe J, Haffajee AD, Socransky SS. Progression of periodontal disease in adult subjects in the absence of periodontal therapy. J Clin Periodontol. 1983;10(4):433-42.

12. Papapanou PN, Wennstrom JL. A 10-year retrospective study of periodontal disease progression. Clinical characteristics of subjects with pronounced and minimal disease development. J Clin Periodontol. 1990;17(2):78-84.

13. Albandar JM. A 6-year study on the pattern of periodontal disease progression. J Clin Periodontol. 1990;17(7 Pt 1):467-71.

14. Machtei EE, Norderyd J, Koch G, Dunford R, Grossi S, Genco RJ. The rate of periodontal attachment loss in subjects with established periodontitis. J Periodontol. 1993;64(8):713-8.

15. Laurell L, Romao C, Hugoson A. Longitudinal study on the distribution of proximal sites showing significant bone loss. J Clin Periodontol. 2003;30(4):346-52.

16. Norderyd O, Hugoson A, Grusovin G. Risk of severe periodontal disease in a Swedish adult population. A longitudinal study. J Clin Periodontol. 1999;26(9):608-15.

17. Ankkuriniemi O, Ainamo J. Dental health and dental treatment needs among recruits of the Finnish Defence Forces, 1919-91. Acta Odontol Scand. 1997;55(3):192-7.

18. Kalsbeek H, Truin GJ, Poorterman JH, van Rossum GM, van Rijkom HM, Verrips GH. Trends in periodontal status and oral hygiene habits in Dutch adults between 1983 and 1995. Community Dent Oral Epidemiol. 2000;28(2):112-8.

19. Borrell LN, Burt BA, Taylor GW. Prevalence and trends in periodontitis in the USA: the [corrected] NHANES, 1988 to 2000. J Dent Res. 2005;84(10):924-30.

20. Skudutyte-Rysstad R, Eriksen HM, Hansen BF. Trends in periodontal health among 35-year-olds in Oslo, 1973-2003. J Clin Periodontol. 2007;34(10):867-72.

21. Borrell LN, Talih M. Examining periodontal disease disparities among U.S. adults 20 years of age and older: NHANES III (1988-1994) and NHANES 1999-2004. Public health reports (Washington, DC : 1974). 2012;127(5):497-506.

22. Schutzhold S, Kocher T, Biffar R, Hoffmann T, Schmidt CO, Micheelis W, et al. Changes in prevalence of periodontitis in two German population-based studies. J Clin Periodontol. 2015;42(2):121-30.

23. Hugoson A, Norderyd O, Slotte C, Thorstensson H. Distribution of periodontal disease in a Swedish adult population 1973, 1983 and 1993. J Clin Periodontol. 1998;25(7):542-8. 
24. Hugoson A, Norderyd O. Has the prevalence of periodontitis changed during the last 30 years? J Clin Periodontol. 2008;35(8 Suppl):338-45.

25. Kassebaum NJ, Bernabe E, Dahiya M, Bhandari B, Murray CJ, Marcenes W. Global burden of severe periodontitis in 1990-2010: a systematic review and meta-regression. J Dent Res. 2014;93(11):104553.

26. Marcenes W, Kassebaum NJ, Bernabe E, Flaxman A, Naghavi M, Lopez A, et al. Global burden of oral conditions in 1990-2010: a systematic analysis. J Dent Res. 2013;92(7):592-7.

27. Last JMe. A dictionary of epidemiology. 4th ed. New York, NY: Oxford University Press; 2001.

28. World Health Organization. Permeable to the Constitution of the world health organization as adopted by the international health conference, New Constitution of the world health organization as adopted by the international health conference, New York, 19-22 June, 1946; signed on 22 July 1946 by the representatives of 61 States (Official Records of the World Health Organization, no. 2, p. 100) and entered into force on April 1948. 1948.

29. Huber M, Knottnerus JA, Green L, van der Horst H, Jadad AR, Kromhout D, et al. How should we define health? BMJ. 2011;343:d4163.

30. Boorse C. Health as a Theoretical Concept. 1977:542.

31. Engel GL. The need for a new medical model: a challenge for biomedicine. Science. 1977;196(4286):129-36.

32. Nordenfelt L. Towards a theory of health promotion: a logical analysis. Linköping: Linköping University Press; 1991.

33. Locker D. Measuring oral health: a conceptual framework. Community Dent Health. 1988;5(1):3-18.

34. Jin L, van Dijk W. Reinforcing and refining oral healthcare. Int Dent J. 2014;64(6):285-6.

35. Allison PJ, Locker D, Feine JS. Quality of life: a dynamic construct. Soc Sci Med. 1997;45(2):221-30.

36. Cohen LK, Jago JD. Toward the formulation of sociodental indicators. Int J Health Serv. 1976;6(4):681-98.

37. Fitzpatrick R, Davey C, Buxton MJ, Jones DR. Evaluating patient-based outcome measures for use in clinical trials. Health Technol Assess. 1998;2(14):i-iv, 1-74.

38. Inglehart MR, Bagramian R, editors. Oral Health-Related Quality of Life. Chicago: Quintessence Publishing Co.; 2002.

39. Slade GD, Spencer AJ. Development and evaluation of the Oral Health Impact Profile. Community Dent Health. 1994;11(1):3-11. 
40. Larsson P, List T, Lundstrom I, Marcusson A, Ohrbach R. Reliability and validity of a Swedish version of the Oral Health Impact Profile (OHIP-S). Acta Odontol Scand. 2004;62(3):147-52.

41. Cunha-Cruz J, Hujoel PP, Kressin NR. Oral health-related quality of life of periodontal patients. J Periodontal Res. 2007;42(2):169-76.

42. Jowett AK, Orr MT, Rawlinson A, Robinson PG. Psychosocial impact of periodontal disease and its treatment with 24-h root surface debridement. J Clin Periodontol. 2009;36(5):413-8.

43. Meusel DR, Ramacciato JC, Motta RH, Brito Junior RB, Florio FM. Impact of the severity of chronic periodontal disease on quality of life. $\mathrm{J}$ Oral Sci. 2015;57(2):87-94.

44. Eltas A, Uslu MO, Eltas SD. Association of Oral Health-related Quality of Life with Periodontal Status and Treatment Needs. Oral Health Prev Dent. 2016;14(4):339-47.

45. Needleman I, McGrath C, Floyd P, Biddle A. Impact of oral health on the life quality of periodontal patients. J Clin Periodontol. 2004;31(6):454-7.

46. Tsakos G, Bernabe E, D’Aiuto F, Pikhart H, Tonetti M, Sheiham A, et al. Assessing the minimally important difference in the oral impact on daily performances index in patients treated for periodontitis. J Clin Periodontol. 2010;37(10):903-9.

47. Santuchi CC, Cortelli JR, Cortelli SC, Cota LO, Fonseca DC, Alencar $\mathrm{CO}$, et al. Scaling and Root Planing per Quadrant Versus OneStage Full-Mouth Disinfection: Assessment of the Impact of Chronic Periodontitis Treatment on Quality of Life--A Clinical Randomized, Controlled Trial. J Periodontol. 2016;87(2):114-23.

48. Mendez M, Melchiors Angst PD, Stadler AF, Oppermann RV, Gomes S. Impacts of supragingival and subgingival periodontal treatments on oral health-related quality of life. Int J Dent Hyg. 2016.

49. Miao L, Feng J, Wu L, Zhang S, Ge Z, Pan Y. The mediating role of general self-efficacy in the association between perceived social support and oral health-related quality of life after initial periodontal therapy. BMC Oral Health. 2016;16(1):68.

50. Saito A, Hosaka Y, Kikuchi M, Akamatsu M, Fukaya C, Matsumoto $\mathrm{S}$, et al. Effect of initial periodontal therapy on oral health-related quality of life in patients with periodontitis in Japan. J Periodontol. 2010;81(7):1001-9.

51. Makino-Oi A, Ishii Y, Hoshino T, Okubo N, Sugito H, Hosaka Y, et al. Effect of periodontal surgery on oral health-related quality of life in patients who have completed initial periodontal therapy. J Periodontal Res. 2016;51(2):212-20.

52. Antonovsky. Health, stress and coping. San Francisco, CA: Jossey-Bass; 1979. 
53. Antonovsky A. Unraveling the mystery of health: how people manage stress and stay well. San Fransisco, CA: Jossey-Bass; 1987.

54. Lindström B, Eriksson M. The hitchhiker's guide to salutogenesis: Salutogenic pathways to health promotion. Helsingfors: Folkhälsan research center, Health promotion research; 2010.

55. Feldt T, Lintula H, Suominen S, Koskenvuo M, Vahtera J, Kivimaki M. Structural validity and temporal stability of the 13-item sense of coherence scale: prospective evidence from the population-based HeSSup study. Qual Life Res. 2007;16(3):483-93.

56. Eriksson M, Lindstrom B. Validity of Antonovsky's sense of coherence scale: a systematic review. J Epidemiol Community Health. 2005;59(6):460-6.

57. Bernabe E, Watt RG, Sheiham A, Suominen-Taipale AL, Uutela A, Vehkalahti MM, et al. Sense of coherence and oral health in dentate adults: findings from the Finnish Health 2000 survey. J Clin Periodontol. 2010;37(11):981-7.

58. Bernabe E, Watt RG, Sheiham A, Suominen AL, Vehkalahti MM, Nordblad A, et al. Childhood socioeconomic position, adult sense of coherence and tooth retention. Community Dent Oral Epidemiol. 2012;40(1):46-52.

59. Lindmark U, Hakeberg M, Hugoson A. Sense of coherence and oral health status in an adult Swedish population. Acta Odontol Scand. 2011;69(1):12-20.

60. Bernabe E, Watt RG, Sheiham A, Suominen-Taipale AL, Nordblad A, Savolainen J, et al. The influence of sense of coherence on the relationship between childhood socioeconomic status and adult oral health-related behaviours. Community Dent Oral Epidemiol. 2009;37(4):357-65.

61. Bernabe E, Kivimaki M, Tsakos G, Suominen-Taipale AL, Nordblad A, Savolainen J, et al. The relationship among sense of coherence, socioeconomic status, and oral health-related behaviours among Finnish dentate adults. Eur J Oral Sci. 2009;117(4):413-8.

62. Lindmark U, Hakeberg M, Hugoson A. Sense of coherence and its relationship with oral health-related behaviour and knowledge of and attitudes towards oral health. Community Dent Oral Epidemiol. 2011;39(6):542-53.

63. Savolainen J, Suominen-Taipale A, Uutela A, Aromaa A, Harkanen T, Knuuttila M. Sense of coherence associates with oral and general health behaviours. Community Dent Health. 2009;26(4):197-203.

64. Elyasi M, Abreu LG, Badri P, Saltaji H, Flores-Mir C, Amin M. Impact of Sense of Coherence on Oral Health Behaviors: A Systematic Review. PloS one. 2015;10(8):e0133918. 
65. Kanhai J, Harrison VE, Suominen AL, Knuuttila M, Uutela A, Bernabe E. Sense of coherence and incidence of periodontal disease in adults. J Clin Periodontol. 2014;41(8):760-5.

66. Cyrino RM, Costa FO, Cortelli JR, Cortelli SC, Cota LO. Sense of coherence and periodontal health outcomes. Acta Odontol Scand. 2016;74(5):368-73.

67. Lundegren N, Axtelius B, Akerman S. Oral health in the adult population of Skane, Sweden: a clinical study. Acta Odontol Scand. 2012;70(6):511-9.

68. Norderyd O, Koch G, Papias A, Kohler AA, Helkimo AN, Brahm CO, et al. Oral health of individuals aged 3-80 years in Jonkoping, Sweden, during 40 years (1973-2013). I. Review of findings on oral care habits and knowledge of oral health. Swed Dent J. 2015;39(2):57-68.

69. Jansson H, Lindholm E, Lindh C, Groop L, Bratthall G. Type 2 diabetes and risk for periodontal disease: a role for dental health awareness. J Clin Periodontol. 2006;33(6):408-14.

70. Landis JR, Koch GG. The measurement of observer agreement for categorical data. Biometrics. 1977;33(1):159-74.

71. Muhlemann HR, Son S. Gingival sulcus bleeding--a leading symptom in initial gingivitis. Helv Odontol Acta. 1971;15(2):107-13.

72. Loe H, Silness J. Periodontal disease in pregnancy. I. Prevalence and severity. Acta Odontol Scand. 1963;21:533-51.

73. Slade GD. Derivation and validation of a short-form oral health impact profile. Community Dent Oral Epidemiol. 1997;25(4):284-90.

74. WMA. World Medical Association. Declaration of Helsinki: ethical principles for medical research involving human subjects. Jama. 2013;310(20):2191-4.

75. Holtfreter B, Demmer RT, Bernhardt O, Papapanou PN, Schwahn C, Kocher T, et al. A comparison of periodontal status in the two regional, population-based studies of SHIP and INVEST. J Clin Periodontol. 2012;39(12):1115-24.

76. Holtfreter B, Kocher T, Hoffmann T, Desvarieux M, Micheelis W. Prevalence of periodontal disease and treatment demands based on a German dental survey (DMS IV). J Clin Periodontol. 2010;37(3):211-9.

77. Dye BA, Tan S, Smith V, Lewis BG, Barker LK, Thornton-Evans G, et al. Trends in oral health status: United States, 1988-1994 and 1999-2004. Vital Health Stat 11. 2007(248):1-92.

78. Bourgeois D, Bouchard P, Mattout C. Epidemiology of periodontal status in dentate adults in France, 2002-2003. J Periodontoal Res. 2007;42(3):219-27.

79. OECD. Health at a Glance 2015: OECD Publishing. 
80. Kongstad J, Enevold C, Christensen LB, Fiehn NE, Holmstrup P. Impact of Periodontitis Case Criteria: A Cross-Sectional Study of Lifestyle. J Periodontol. 2017:1-10.

81. Grossi SG, Zambon JJ, Ho AW, Koch G, Dunford RG, Machtei EE, et al. Assessment of risk for periodontal disease. I. Risk indicators for attachment loss. J Periodontol. 1994;65(3):260-7.

82. Muller F, Naharro M, Carlsson GE. What are the prevalence and incidence of tooth loss in the adult and elderly population in Europe? Clinical Oral Implants Res. 2007;18 Suppl 3:2-14.

83. Wennstrom A, Ahlqwist M, Stenman U, Bjorkelund C, Hakeberg M. Trends in tooth loss in relation to socio-economic status among Swedish women, aged 38 and 50 years: repeated cross-sectional surveys 19682004. BMC Oral Health. 2013;13:63.

84. Schneider C, Zemp E, Zitzmann NU. Oral health improvements in Switzerland over 20 years. Eur J Oral Sci. 2017;125(1):55-622017.

85. Kassebaum NJ, Bernabe E, Dahiya M, Bhandari B, Murray CJ, Marcenes W. Global Burden of Severe Tooth Loss: A Systematic Review and Meta-analysis. J Dent Res. 2014;93(7 Suppl):20s-8s.

86. Loe H, Anerud A, Boysen H, Smith M. The natural history of periodontal disease in man. Tooth mortality rates before 40 years of age. J Periodontal Res. 1978;13(6):563-72.

87. Norderyd O, Koch G, Papias A, Kohler AA, Helkimo AN, Brahm CO, et al. Oral health of individuals aged 3-80 years in Jonkoping, Sweden during 40 years (1973-2013). II. Review of clinical and radiographic findings. Swed Dent J. 2015;39(2):69-86.

88. Klock KS, Haugejorden O. Primary reasons for extraction of permanent teeth in Norway: changes from 1968 to 1988. Community Dent Oral Epidemiol. 1991;19(6):336-41.

89. Albrecht GL, Devlieger PJ. The disability paradox: high quality of life against all odds. Soc Sci Med. 1999;48(8):977-88.

90. Slade GD, Sanders AE. The paradox of better subjective oral health in older age. J Dent Res. 2011;90(11):1279-85.

91. Steele JG, Sanders AE, Slade GD, Allen PF, Lahti S, Nuttall N, et al. How do age and tooth loss affect oral health impacts and quality of life? A study comparing two national samples. Community Dent Oral Epidemiol. 2004;32(2):107-14.

92. Locker D, Allen PF. Developing short-form measures of oral healthrelated quality of life. J P Health Dent. 2002;62(1):13-20.

93. Locker D, Allen F. What do measures of 'oral health-related quality of life' measure? Community Dent Oral Epidemiol. 2007;35(6):401-11. 
94. Tsakos G, Allen PF, Steele JG, Locker D. Interpreting oral health-related quality of life data. Community Dent Oral Epidemiol. 2012;40(3):193200.

95. Hendrikx T, Nilsson M, Westman G. Sense of coherence in three crosssectional studies in Northern Sweden 1994, 1999 and 2004 -- patterns among men and women. Scandinavian J Public Health. 2008;36(4):3405.

96. Boman UW, Wennstrom A, Stenman U, Hakeberg M. Oral healthrelated quality of life, sense of coherence and dental anxiety: an epidemiological cross-sectional study of middle-aged women. BMC Oral Health. 2012;12:14.

97. Nyman S, Lindhe J, Rosling B. Periodontal surgery in plaque-infected dentitions. J Clin Periodontol. 1977;4(4):240-9.

98. Rosling B, Nyman S, Lindhe J, Jern B. The healing potential of the periodontal tissues following different techniques of periodontal surgery in plaque-free dentitions. A 2-year clinical study. J Clin Periodontol. 1976;3(4):233-50.

99. Zimmermann H, Zimmermann N, Hagenfeld D, Veile A, Kim TS, Becher $\mathrm{H}$. Is frequency of tooth brushing a risk factor for periodontitis? A systematic review and meta-analysis. Community Dent Oral Epidemiol. 2015;43(2):116-27.

100. Flensborg-Madsen T, Ventegodt S, Merrick J. Sense of coherence and physical health. A review of previous findings. ScientificWorldJournal. 2005;5:665-73.

101. Albandar JM. Underestimation of periodontitis in NHANES surveys. J Periodontol. 2011;82(3):337-41.

102. Tran DT, Gay I, Du XL, Fu Y, Bebermeyer RD, Neumann AS, et al. Assessing periodontitis in populations: a systematic review of the validity of partial-mouth examination protocols. J Clin Periodontol. 2013;40(12):1064-71.

103. Holde GE, Oscarson N, Tillberg A, Marstrander P, Jonsson B. Methods and background characteristics of the TOHNN study: a populationbased study of oral health conditions in northern Norway. Int J Circumpolar Health. 2016;75:30169.

104. Page RC, Eke PI. Case definitions for use in population-based surveillance of periodontitis. J Periodontol. 2007;78(7 Suppl):1387-99.

105. Holtfreter B, Albandar JM, Dietrich T, Dye BA, Eaton KA, Eke PI, et al. Standards for reporting chronic periodontitis prevalence and severity in epidemiologic studies: Proposed standards from the Joint EU/ USA Periodontal Epidemiology Working Group. J Clin Periodontol. 2015;42(5):407-12. 


\section{APPENDIX}

The OHIP-14 questionnaire (Swedish)

Hur ofta har Du Till följd av din mun, dina tänder eller proteser, under det senaste året, upplevt följande situationer

\begin{tabular}{|c|c|c|c|c|c|c|}
\hline & $\begin{array}{l}\text { Frågan } \\
\text { går ej att } \\
\text { tillämpa } \\
\text { på mig }\end{array}$ & $\begin{array}{l}\text { Mycket } \\
\text { ofta }\end{array}$ & $\begin{array}{l}\text { Ganska } \\
\text { ofta }\end{array}$ & Ibland & Sällan & Aldrig \\
\hline Svårigheter med att uttala or & & & & & & \\
\hline $\begin{array}{l}\text { Känt att smakförmågan har } \\
\text { försämrats }\end{array}$ & & & & & & \\
\hline Har haft smärta i din mun & & & & & & \\
\hline $\begin{array}{l}\text { Har haft obehag med att äta } \\
\text { mat }\end{array}$ & & & & & & \\
\hline Känt dig osäker & & & & & & \\
\hline Känt dig spänd & & & & & & \\
\hline $\begin{array}{l}\text { Har haft en otillfredsställand } \\
\text { kost }\end{array}$ & & & & & & \\
\hline $\begin{array}{l}\text { Har varit tvungen att avbryta } \\
\text { måltider }\end{array}$ & & & & & & \\
\hline Har haft svårt att koppla av & & & & & & \\
\hline Blivit generad & & & & & & \\
\hline $\begin{array}{l}\text { Varit irriterad på andra } \\
\text { människor }\end{array}$ & & & & & & \\
\hline $\begin{array}{l}\text { Haft svårigheter att utföra de } \\
\text { vardagliga sysslorna }\end{array}$ & & & & & & \\
\hline $\begin{array}{l}\text { Känt att livet i allmänhet har } \\
\text { varit mindre tillfredsällande }\end{array}$ & & & & & & \\
\hline $\begin{array}{l}\text { Varit totalt oförmögen att } \\
\text { fungera }\end{array}$ & & & & & & \\
\hline
\end{tabular}




\title{
The Orientation to life questionnaire (Swedish)
}

Reprinted with permission of: Dr. Avishai Antonovsky, by Monica Eriksson, PhD, Associate Professor Department of Health Sciences, University West, Center on Salutogenesis, Trollhättan, Sweden

\begin{abstract}
Här är några frågor som berör skilda områden i livet. Varje fråga har 7 möjliga svar. Var snäll och markera den siffra som passar bäst in på ditt svar. Siffran 1 eller 7 är svarens yttervärden. Om du instämmer i det som står under 1, så ringa in 1:an; om du instämmer med det som står under 7 så ringa in 7:an. Om du känner annorlunda, ringa in den siffra som bäst överensstämmer med din känsla. Ge endast ett svar på varje fråga.
\end{abstract}

Har du en känsla av att du inte riktigt bryr dig om vad som händer runt omkring dig?

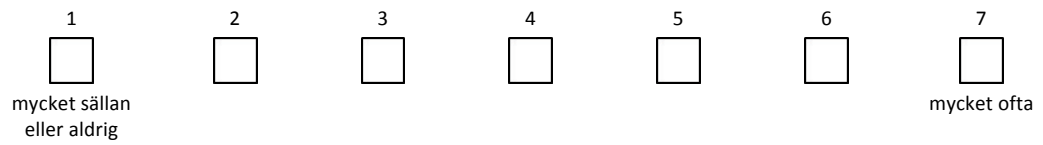

Har det hänt att du blivit överraskad av beteendet hos personer som du trodde du kände väl?

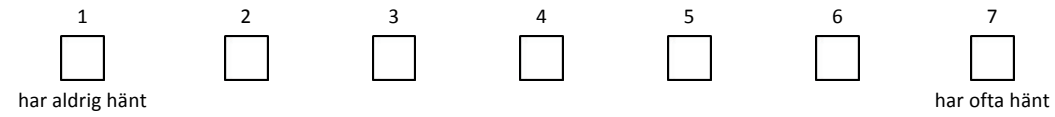

Har det hänt att människor som du litade på har gjort dig besviken?

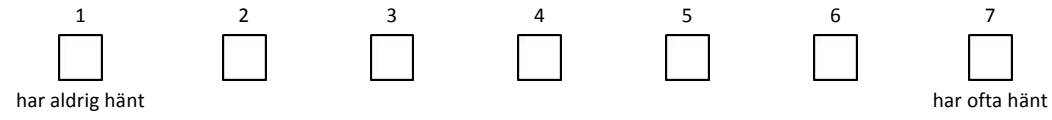

Hittills har ditt liv:

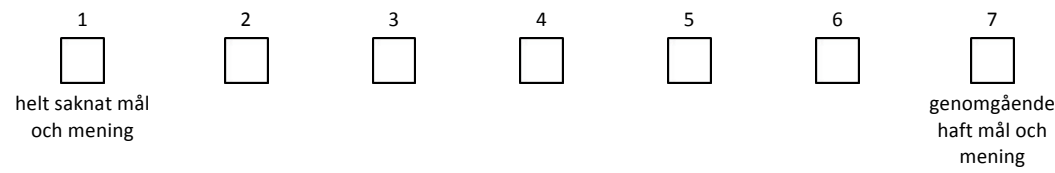

Känner du dig orättvist behandlad?

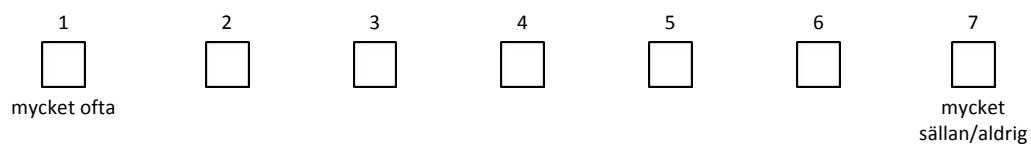

Har du en känsla av att du befinner dig i en obekant situation och inte vet vad du skall göra?
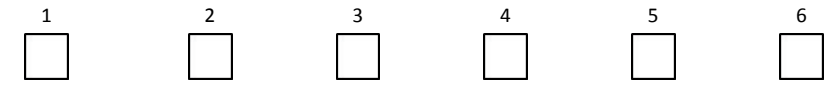

mycket ofta

Är dina dagliga sysslor en källa till:
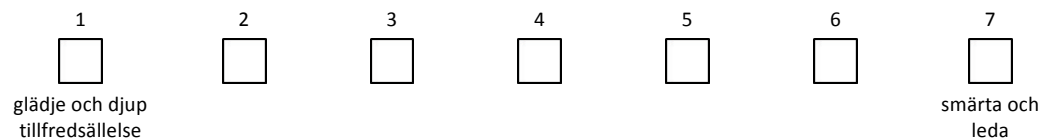
Har du mycket motstridiga känslor och tankar?

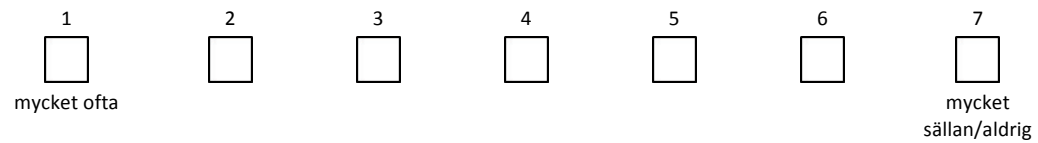

Händer det att du har känslor innom dig som du helst inte vill känna?

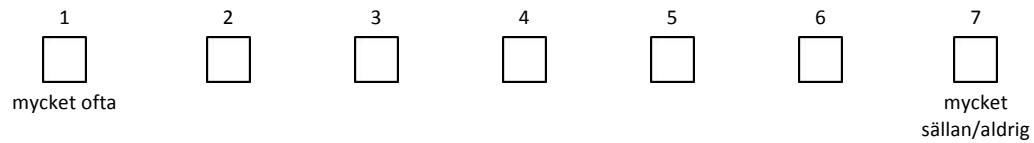

Även människor med stark självkänsla kan ibland känna sig som en "olycksfågel". Hur ofta har du kännt det så?

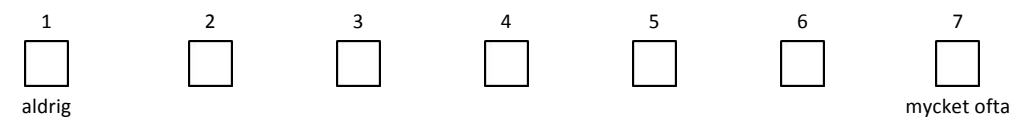

När något har hänt, har du vanligtvis funnit att:

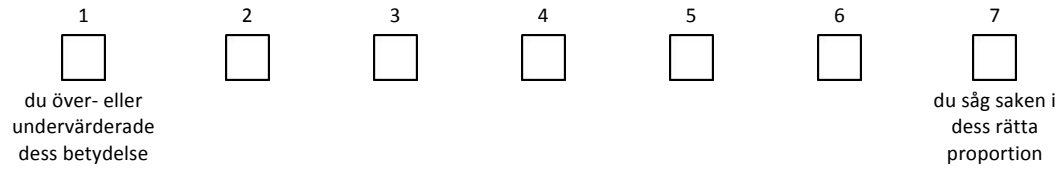

Hur ofta känner du att det inte är någon mening med de saker du gör I ditt dagliga liv?

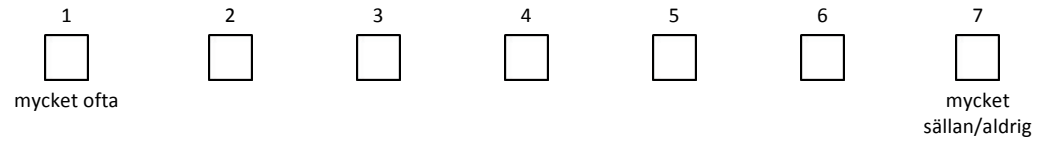

Hur ofta har du känslor som du inte är säker på att du kan kontrollera?

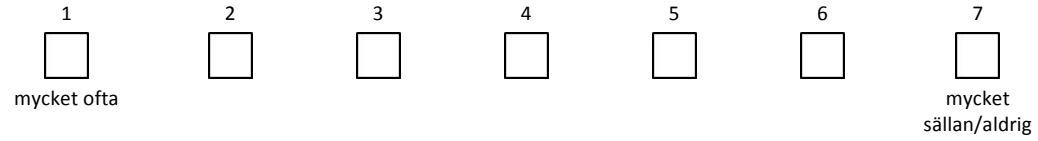



PAPERS I-IV 

I 



\title{
Marginal bone loss in the adult population in the county of Skåne, Sweden
}

\author{
Åsa Wahlin', Henrik JANSSON ${ }^{1}$, BJörn KLINGE ${ }^{1,2}$, Nina LUNDEG ReN ${ }^{3}$, \\ Sigvard ÅKerman ${ }^{3}$, Ola Norderyd ${ }^{1,4}$
}

Abstract

(2) The aim of this study was to investigate the prevalence and extent of periodontal disease registered as marginal bone loss and subject characteristics in the adult population in the county of Skåne in Sweden.

One thousand individuals, 20-89 years old, were randomly selected and 451 subjects agreed to participate in the study. They answered a questionnaire and in conjunction with the clinical and radiological examination the subjects answered questions about their medical history. The examiners were co-ordinated regarding the diagnostic criteria through comprehensive written instructions, practice and discussions of clinical cases. One observer estimated marginal bone loss around the teeth on digital panoramic radiographs and bitewings. The individuals were classified regarding periodontal disease experience according to the following criteria: PD- = loss of supporting bone tissue $<1 / 3$ of the root length, PD = loss of supporting bone tissue $\geq 1 / 3$ of the root length in $<30 \%$ of the teeth and PD+ = loss of supporting bone tissue $\geq 1 / 3$ the root length in $\geq 30 \%$ of the teeth.

Subjects with no or minor bone loss, i.e. PD- constituted $69 \%$ of the population. Twenty percent of the study population had marginal bone loss corresponding to localised periodontal disease (PD) and $11 \%$ exhibited generalised periodontal bone loss (PD+). The periodontal treatment need, defined as probing pocket depth $\geq 6 \mathrm{~mm}$ and bleeding on probing $\geq 20 \%$, was $53 \%$ in the PD+ group. An interesting result was that there were no differences in periodontal disease experience between the genders.

Conclusions: The prevalence and extent of periodontal disease in this study correlates well with recent other studies. Eleven percent of the population has experienced generalised periodontal disease, and $53 \%$ of them have a periodontal treatment need defined as 1 or more site with PPD $\geq 6 \mathrm{~mm}$ and $\mathrm{BoP} \geq 20 \%$.

Key words

Epidemiology, periodontal disease; periodontitis, prevalence, marginal bone loss 


\title{
Parodontala skador hos vuxna i Skåne
}

\author{
Åsa Wahlin, Henrik Jansson, BJörn Klinge, Nina Lundegren, \\ SigVard Åkerman, Ola Norderyd
}

\section{Sammanfattning}

() Syftet med studien var att undersöka förekomst och omfattning av parodontala skador samt individuella bakgrundsfaktorer i den vuxna befolkningen i Skåne.

Ett tusen slumpmässigt utvalda individer, 20-89 år och registrerade som boende i Skåne, erbjöds att delta i studien. Fyrahundrafemtioen individer besvarade en enkät och efter anamnestagning utfördes en klinisk och radiologisk undersökning. Observatörerna hade koordinerats avseende diagnostiska kriterier genom skriftliga instruktioner, kliniska övningar och falldiskussioner. En observatör skattade förlust av marginalt ben med hjälp av digitala panoramaröntgen och bitewings i bettets sidopartier utan annan information om individerna utöver röntgenbilderna.

De undersökta individerna delades in i 3 grupper beroende på omfattning av förlust av marginalt ben: PD- = förlust av marginalt ben omfattande $<1 / 3$ av rotlängden, $P D=$ förlust av marginalt ben omfattande $\geq 1 / 3$ rotlängden hos $\geq 30 \%$ av bettets tänder och PD $+=$ förlust av marginalt ben omfattande $\geq 1 / 3$ rotlängden hos $\geq 30 \%$ av bettets tänder.

I den undersökta populationen hade $69 \%$ av individerna ingen eller ringa förlust av marginalt ben (PD-). Tjugo procent av personerna hade lokalt förlust av marginalt ben (PD), och $11 \%$ uppvisade generell benförlust i bettet (PD+). Parodontalt behandlingsbehov, definierat som fickdjup $\geq 6 \mathrm{~mm}$ och blödning vid sondering $\geq 20 \%$, uppgick till $53 \%$ av individerna i PD+ gruppen.

Ett intressant fynd var att skillnad mellan män och kvinnor avseende parodontal benförlust inte kunde påvisas i denna population.

Sammanfattningsvis korrelerar prevalens och omfattning av parodontala skador i denna population väl med andra studier. Elva procent av populationen har eller har haft avancerad generell parodontit, och $53 \%$ av dessa individer har behov av parodontal behandling, definierat som en eller flera fickor $\geq 6 \mathrm{~mm}$ och BoP $\geq 20 \%$. 


\section{Introduction}

Periodontitis is defined as an infectious disease that causes inflammation in the supportive tissues of the tooth, which leads to loss of the periodontium and surrounding alveolar bone. Gingivitis and periodontitis used to be considered as an expression of the same disease entity. Today periodontitis is seen as separate from gingivitis due to the destruction of supportive tissues of the tooth (16).

Periodontitis is a result of an imbalance between the oral biofilm in the dento-gingival area and the host response. This will result in loss of supporting periodontal ligaments and alveolar bone $(6,16)$. Loss of supportive tissues around the teeth of varying degree is common in an adult population. In the latest survey in the Jönköping studies $39 \%$ of 50 -year olds show some degree of periodontal bone loss. In this Swedish population subjects with advanced alveolar bone loss comprise $11 \%$ of all examined adults (14, 19, 21, 22).

Improved oral health in the adult population has resulted in a decreased number of edentulous individuals and concomitantly in an increased number of individuals with more remaining teeth. However, despite these improvements approximately $10 \%$ of the population suffers from severe periodontal disease $(19,21,22)$. Men exhibit more advanced periodontal disease in several studies in different populations. They exhibit more marginal bone loss compared to women and also more pronounced attachment loss $(1,15,18)$. When planning for health care resources, the treatment need in a population, needs to be documented.

The aim of this study was to investigate the prevalence and extent of marginal bone loss and subject characteristics in the adult population in the county of Skåne, Sweden.

\section{Materials and methods \\ Study subjects}

The outline and results of the clinical examination, radiographs and questionnaires are previously published by Lundegren et al 2012 (25). One thousand individuals were randomly selected from the Governments Person Address Register (SPAR), and were recruited for the study. They were 20-89 years old and registered as living in the county of Skane in the southern part of Sweden in 2007. Skåne had a population of 907702 individuals in the age group 20-89 years, in 2007. Of the original sample 11 had moved from the region, 14 had an unknown address and 9 were deceased, thus leaving 966 subjects as the final sample. 451 individuals agreed to participate in the clinical study and were examined both clinically and radiographically.

Eight individuals were excluded from this study for the following reasons: two subjects were edentulous, one individual was edentulous but restored with dental implants, radiographs were missing in four subjects and one individual were excluded due to poor quality of the radiographs, resulting in 443 individuals in the present study.

\section{Questionnaire}

All study subjects, except one, answered a questionnaire. The questionnaire contained 58 questions regarding patient's perception of oral health, need of oral health care, pain in the head, neck and oral region, use of dental health care, dental materials and background factors (25).

In the present study we focus on questions regarding gender, ethnicity, level of education, demographic status, self-reported cardiovascular disease and tobacco use.

\section{Clinical examination}

The clinical examinations were performed in standard dental surgeries from March 2007 to November 2008 , the majority ( $83 \%$ ) at the Faculty of Odontology, Malmö University, Sweden. As reported by Lundegren et al (25) the majority (91\%) of the examinations were performed by eight dentists all employed at the Department of Oral Diagnostics. All examiners were co-ordinated regarding the diagnostic criteria through comprehensive written instructions, clinical practice and discussions of clinical cases. A standardised examination protocol was used. Subjects unable to come to Malmö for the examination were examined at clinics of the Public Dental Health Service in Helsingborg, Kristianstad or Ystad.

All clinical periodontal measurements were recorded at 4 sites (buccal-mesial-lingual-distal) on each tooth. Third molars, root remnants and dental implants were excluded in all measurements. Presence of visible plaque was recorded. Probing pocket depth (PPD) was measured parallel to the tooth with a periodontal probe with $1 \mathrm{~mm}$ grading $(\mathrm{Hu}$ Friedy PCPUNC157). The deepest pocket $\geq 4 \mathrm{~mm}$ was registered. Bleeding on probing $(\mathrm{BoP})$ was recorded after probing of the pockets.

\section{Radiographic examination}

Digital panoramic radiographs were taken on all subjects. Bilateral bitewings were performed on all dentate subjects. In the present study the digital radiographs 
were analysed regarding marginal bone loss by one calibrated examiner ( $\AA \mathrm{W})$, as described by Jansson et al (23). Except for the digital radiographs the examiner did not have access to any information regarding the study subjects. All other information, regarding the individuals, had been removed prior to the reading. The number of teeth was recorded, excluding third molars and root remnants. All measures were conducted on the computer screen using a digital ruler. The teeth were measured mesial and distal, parallel to the long axis of the tooth, from the cement-enamel junction to apex and from the most coronal marginal bone level. The site having most pronounced bone loss represented the tooth as a whole.

The individuals were classified regarding periodontal disease experience according to the following criteria:

PD- = loss of supporting bone $<1 / 3$ of the root length.

$\mathrm{PD}=$ loss of supporting bone tissue $\geq 1 / 3$ the root length in $<30 \%$ of the teeth.

$\mathrm{PD}+=$ loss of supporting bone tissue $\geq 1 / 3$ the root length in $\geq 30 \%$ of the teeth.

\section{Non-response}

A non-response analysis were performed and described in detail by Lundegren et al. (25). The non-respondents were contacted by telephone and were invited to be part of a non-response analysis. One hundred seventy five individuals answered the same questionnaire as the subjects participating in the clinical study.

\section{Statistical analyses}

Descriptive analyses, mean values and standard devia- tions were calculated based on the subject as the unit. For numerical variables the comparisons between different PD-groups were analysed using a General Linear Model. For binary variables the analyses were logistic regressions, using the likelihood-ratio test. All group comparisons were adjusted for differences in age, gender and smoking habits. A significance level of $\alpha=5 \%$ were used in all tests (two-tailed). All analyses were made using the statistical software SPSS (version 20, USA).

Reproducibility of radiographic measurements In order to calculate intra observer agreement, the assessments of the marginal bone level were repeated in 100 randomly selected individuals. A Kappa value of $80 \%$ was calculated, on individual level.

\section{Results}

Subjects with no or minor bone loss, i.e. group PD-, comprised $69 \%$ of the examined population. The PD group, i.e. individuals with localised periodontal bone loss, consisted of $20 \%$ of the examined population, and the group with generalised periodontal bone loss consisted of $11 \%$ of the examined population (Figure 1).

The mean age in the different groups was 42 years (PD-), 60 years (PD) and 64 years (PD+). The individuals with no or minor marginal bone loss (PD-) were significantly younger than the groups with a more pronounced periodontal bone loss (PD and $\mathrm{PD}+)$ (Table 1).

There was no difference in presence of marginal bone loss or PPD $\geq 6 \mathrm{~mm}$ between the genders. However, differences between females and males were

(2) Figure 1. Distribution of periodontal bone loss in adult individuals in the county of Skåne, Sweden $(n=443)$.

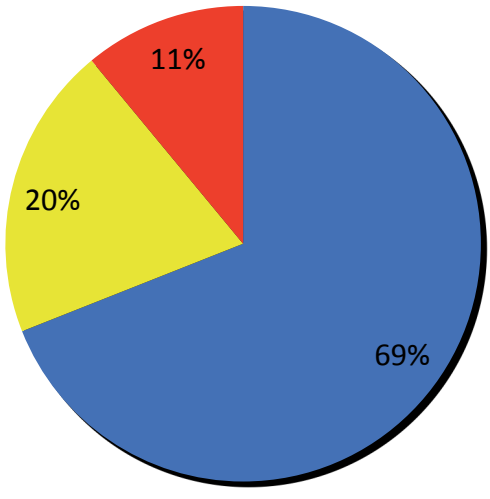

DD- $=$ loss of supporting bone $<1 / 3$ of the root length

PD = loss of supporting bone tissue $\geq 1 / 3$ of the root length in $<30 \%$ of the teeth

- $\mathrm{PD}+=$ loss of supporting bone tissue $\geq 1 / 3$ the root length in $\geq 30 \%$ of the teeth 
Table 1. Subject characteristic of individuals distributed in three groups, PD-, PD and PD+, based on marginal bone loss in radiographs.

\begin{tabular}{|c|c|c|c|c|c|}
\hline & & $\begin{array}{c}P D- \\
n=304\end{array}$ & $\begin{array}{c}P D \\
n=90\end{array}$ & $\begin{array}{c}P D+ \\
n=49\end{array}$ & P-value \\
\hline $\begin{array}{l}\text { Mean age } \\
\text { Gender (\%) }\end{array}$ & $n=443$ & $42^{*}$ & 60 & 64 & $\leq 0.001$ \\
\hline Female & $n=228$ & 52 & 56 & 41 & ns \\
\hline Male & $n=215$ & 48 & 44 & 59 & \\
\hline \multicolumn{6}{|l|}{ Ethnicity (\%) } \\
\hline Nordic countries & $n=374$ & 86 & 85 & 78 & ns \\
\hline Non-Nordic countries & $n=66$ & 14 & 15 & 22 & \\
\hline University degree (\%) & $n=149$ & $39 *$ & 28 & 17 & $\leq 0.001$ \\
\hline \multicolumn{6}{|l|}{ Demographic status (\%) } \\
\hline Malmö & $n=129$ & 30 & 26 & 29 & ns \\
\hline Skåne & $n=314$ & 70 & 74 & 71 & \\
\hline \multicolumn{6}{|l|}{ Self-reported } \\
\hline cardiovascular disease (\%) & $n=443$ & $4^{*}$ & 14 & 25 & $\leq 0.001$ \\
\hline Smoking (\%) & $n=443$ & 16 & 13 & 29 & ns \\
\hline Moist snuff (\%) & $n=442$ & 11 & 7 & 2 & ns \\
\hline
\end{tabular}

* PD- significantly different compared to PD and PD+

** Significant difference between PD- and PD+

(2) Table 2. Clinical characteristics of individuals distributed in three groups, PD-, PD and PD+, based on marginal bone loss in radiographs ( $n=443$ ) adjusted for age, gender and smoking. Plaque index (PI), Bleeding on Probing (BoP) and Probing Pocket Depth (PPD).

\begin{tabular}{lllll}
\hline & PD- & PD & PD+ & P-value \\
\hline Mean number of teeth & $26(s \mathrm{~s} \pm 4)^{*}$ & $25(\mathrm{sd} \pm 3)^{*}$ & $22(\mathrm{sd} \pm 5)^{*}$ & $\leq 0.001$ \\
PI (\%) & $20(\mathrm{sd} \pm 18) * *$ & $23(\mathrm{sd} \pm 23)$ & $31(\mathrm{sd} \pm 29) * *$ & 0.025 \\
BoP $(\%)$ & $29(\mathrm{sd} \pm 20)$ & $28(\mathrm{sd} \pm 20)$ & $31(\mathrm{sd} \pm 25)$ & $\mathrm{ns}$ \\
PPD 4-5mm (\%) & $5(\mathrm{sd} \pm 7) *$ & $9(\mathrm{sd} \pm 8) *$ & $17(\mathrm{sd} \pm 14) *$ & $\leq 0.001$ \\
PPD $\geq 6 \mathrm{~mm}(\%)$ & $0.2(\mathrm{sd} \pm 0.6)$ & $0.6(\mathrm{sd} \pm 1.5)$ & $4(\mathrm{sd} \pm 5.5) * * *$ & $\leq 0.001$ \\
PPD $\geq 4-5 \mathrm{~mm}$ and BoP $\geq 20 \%(\%)$ & 49 & 59 & 61 & $\mathrm{~ns}$ \\
PPD $\geq 6 \mathrm{~mm}$ and BoP $\geq 20 \%(\%)$ & $11^{*}$ & $24^{*}$ & $53^{*}$ & $\leq 0.001$ \\
\hline
\end{tabular}

* Significant differences between all three groups

** Significant difference between PD- and PD+

*** PD+ significantly different compared to PD and PD-

seen in mean dental plaque ( 18 versus $27 \%$, p $\leq 0.001$ ) and in mean bleeding on probing ( 27 versus $31 \%$, $\mathrm{p}=0.018$ ). There was no difference in marginal bone loss between subjects born in the Nordic countries compared to individuals born outside the Nordic countries. A comparison between the population of the city of Malmö, where approximately one third of the population have a non-Nordic background, and the rest of the county of Skåne showed no difference in periodontal disease experience (Table 1).

In the total sample $34 \%$ of participants had a university education. The percentage of individuals with a university degree was significantly higher in the group PD- than in groups PD and PD+ $(\mathrm{p}=\leq 0.001)$. Thirty-nine percent of the PD- group had a university education, compared to $28 \%$ of the
$\mathrm{PD}$ group and $17 \%$ of the $\mathrm{PD}+$ group. The percentage of individuals reporting cardiovascular disease was significantly higher in the PD and PD+ groups than in the PD- group ( $\mathrm{p} \leq 0.001)$. When looking at tobacco habits, there was no significant difference between groups PD-, PD and PD+ in percentage daily smokers. There were no difference in periodontal disease experience between subjects using Swedish moist snuff and subjects not using moist snuff (Table 1).

The mean number of teeth in the examined individuals was 26,25 and 22 in the periodontal disease groups PD-, PD and PD+ respectively. These differences were statistically significant between all groups (Table 2). Regarding oral hygiene in the study population, the mean percent plaque scores were 20, 23, and 31 in PD-, PD and PD+ groups, respectively. The 
PD- group had significantly less plaque than the PD+ group. The degree of gingival inflammation expressed as bleeding on probing (BoP) did not differ between individuals with different levels of periodontal disease experience.

There were significant differences between all groups regarding mean percentage of probing pocket depths (PPD) 4-5mm. The PD+ group had significantly more $\mathrm{PPD} \geq 6 \mathrm{~mm}$ compared to both $\mathrm{PD}$ and PD-. The mean percentage of PPD 4-5mm and $\geq$ $6 \mathrm{~mm}$ were $5,9,17$ and $0.2,0.6,4$ in the PD-, PD and $\mathrm{PD}+$ groups, respectively. Clinical periodontal treatment need defined as at least one site with PPD 4-5mm and full mouth $\mathrm{BoP} \geq 20 \%$ was $49 \%$ in the $\mathrm{PD}$ - group, $59 \%$ in the $\mathrm{PD}$ group and $61 \%$ in the $\mathrm{PD}+$ group, there were no statistical difference between the groups.

The periodontal treatment need defined as PPD ( $\geq 1$ pocket) $\geq 6 \mathrm{~mm}$ and bleeding on probing $\geq 20 \%$ was significantly different between all three groups. The percentage of examined individuals with a periodontal clinical treatment need were $11 \%, 24 \%$ and $53 \%$ in the PD-, PD and PD+ groups, respectively.

\section{Non-response}

One hundred and seventy five of the non-respondent individuals answered the same questionnaire as the participants in the clinical study for a non-response analysis. There were a significant difference in participation due to age $(\mathrm{p}=0.002)$; individuals in the age group $80-89$ were less likely to participate. There were no significant differences between the genders. Twentyfour percent of the individuals in the group only answering the questionnaire had a university degree compared to $34 \%$ in the clinical study. In the non-response group $11 \%$ reported that they were missing $>10$ teeth compared to $4 \%$ of those participating in the clinical study $(\mathrm{p}=0.014)$. There were significantly more smokers in the group that only answered the questionnaire compared to the clinical study $(\mathrm{p}=0.039)$ and there were significantly more subjects born in Sweden in the group only answering the questionnaire $(\mathrm{p}=0.023)$.

Of those who did not participate in the present study or answer the non-response questionnaire, $48 \%$ were women and $52 \%$ men. Men in the age group 30-39 were the largest non-participating group.

\section{Discussion}

The prevalence of pronounced periodontal bone loss, defined as marginal bone loss on radiographs, was $11 \%$. This is in agreement with previous findings of the incidence of severe periodontal disease in Sweden $(14,19$, 21). Hugoson et al. (19) reported a prevalence of severe periodontal disease of $11 \%$. They used another classification of periodontal disease according to Hugoson \& Jordan (20). In that classification group 4 had alveolar bone loss around the majority of the teeth ranging between $1 / 3$ and $2 / 3$ of the length of the roots and group 5 had alveolar bone loss around the majority of the teeth exceeding $2 / 3$ of the length of the roots; presence of angular bony defects and/or furcation defects. These groups can be considered comparable to the $\mathrm{PD}+$ group in the present study. Edman et al (14) reported a prevalence of advanced periodontitis of $9.2 \%$ in 2008 , in the county of Dalarna in Sweden. They defined advanced periodontitis as alveolar bone loss exceeding more than $1 / 3$ of the length of the roots, furcation defects II and III and/or angular bony defects on $>3$ teeth in the molar and premolar regions.

The PD- group had a mean age of 42 years, the corresponding age for the $\mathrm{PD}$ and $\mathrm{PD}+$ group were 60 and 64 years respectively. The PD+ and the PD group were significantly older than the $\mathrm{PD}$ - group. This is in accordance with other studies $(8,15,17)$ that have shown increased marginal bone loss with increasing age. The difference in periodontal disease experience can to some degree be explained by age.

Regarding the number of remaining teeth there was a statistical significant difference between all three groups. The mean number of teeth in the study groups was 26 teeth in the PD- group, 25 teeth in the PD group and 22 teeth in the PD+ group. These numbers are comparable to the number of remaining teeth in the different study groups in the Jönköping studies. The difference in the number of remaining teeth can largely be explained by periodontal disease progression. Holtfreter el al. (17) found that increasing tooth loss was associated with increased attachment loss values. In a recently published study from Germany (18), the mean remaining number of teeth was 25 teeth in the age group 35-44 years and 14 teeth in the age group 65-74 years. The higher number of remaining teeth reported in the different Swedish studies might be explained by the preventive work that has been performed in Sweden for several decades. It is difficult to make comparisons with other studies due to different classifications of the population.

Periodontitis has been shown to be the main cause of tooth loss after the age of 45 (24). Other explanations can be caries, endodontic problems and technical failures, especially in the older age groups. The mean plaque score was $20 \%$ in the PD- group compared to $31 \%$ in the PD+ group, and this difference was statistically significant. The results regarding 
mean plaque score is in accordance with the Jönköping study. The plaque score is presented as a mean for the individual. Presence of bacterial plaque is necessary for periodontal disease development. However, plaque as a diagnostic variable is not very useful in epidemiological studies due to general presence of proximal plaque in a population regardless of their level of periodontal health/disease (12).

In the present study there was no difference in periodontal bone loss or presence of $\mathrm{PPD} \geq 6 \mathrm{~mm}$ between the genders. However, significant differences between females and males were seen in the mean dental plaque and in mean BoP, males having more plaque and BoP. Norderyd \& Hugoson (27), Norderyd et al. (28) reported no differences in periodontal disease experience, in a Swedish population, between male and female gender. There were no differences in oral hygiene and dental-visit behaviour between the genders (28). Bahrami et al. (4) showed no differences between male and female gender in marginal bone level in an adult Danish population when looking at radiographs nor were there any difference between the genders in the county of Dalarna in Sweden regarding marginal bone loss (14). This is in contrast to many other studies, for example Albandar et al. (1), Holtfreter et al. (17), Bourgeois et al. (8), that report deeper probing depths and more clinical attachment loss in males than females in the United States of America, Germany and France, respectively. As discussed previously the difference between the present study and the others could be due to a long tradition of preventive dental care in Scandinavia (2, $19,21,22,30)$.

In the PD+ group $17 \%$ stated that they had a university education. This was significantly fewer than in the PD and PD- groups, and is in agreement with another study from Sweden (29). Paulander et al. (29) reported a significantly higher proportion of subjects with a low educational level in the group with the most extensive probing attachment loss (PAL). The difference in having a university degree has to be interpreted with care. A low number of the study subjects answered the question about education level $(\mathrm{n}=149)$. The PD- group was significantly younger than the other two groups and thus had less accumulated periodontal bone loss.

In the present study there was no difference with regard to periodontal disease experience between subjects who were born in Sweden-Denmark-Norway-Finland-Iceland and subjects from countries outside the Nordic countries. A comparison between individuals with Nordic background and in- dividuals with non-Nordic background showed no difference in marginal bone level. Due to the low number of individuals with a non-Nordic background, it is difficult to interpret these findings.

Clinical periodontal treatment need defined as full mouth $\mathrm{BoP} \geq 20 \%$ and at least one site with PPD $4-5 \mathrm{~mm}$ was $49 \%$ in the PD- group, $59 \%$ in the $\mathrm{PD}$ group and $61 \%$ in the $\mathrm{PD}+$ group. When the definition of clinical treatment need was full mouth $\mathrm{BoP} \geq 20 \%$ and at least one site with PPD $\geq 6 \mathrm{~mm}, 11 \%$ in the PD- group, $24 \%$ in the PD group and $53 \%$ in the PD+ group needed periodontal treatment. In the total sample $18 \%$ of the individuals were defined as having full mouth $\mathrm{BoP} \geq 20 \%$ and at least one site with PPD $\geq 6 \mathrm{~mm}$. This means that a relatively high number of individuals are in need of some degree of periodontal treatment. Claffey \& Egelberg (11) reported that high numbers of deep residual periodontal pockets in individuals treated for periodontitis were associated with higher risk for disease progression.

When planning for dental health care on a national level it is important to maintain periodontal health but also to allocate resources to the large group of individuals with periodontits. Despite better periodontal health in the population at large $(14,19,21,22)$ still more can be done for individuals most sensitive to periodontal disease.

Several cohort and case-control studies have reported an association between cardiovascular disease (CVD) and periodontitis $(5,13,26)$. Individuals with severe periodontitis have elevated levels of known risk markers for atherosclerosis and with periodontal treatment some of the risk marker levels are reduced $(9,10)$. In this study there was more selfreported CVD experience in the $\mathrm{PD}+$ group compared to the PD and PD- groups. If it is a causal relation or a co-variation due to age difference between the groups is not known.

There were no differences in the number of daily smokers between the three groups in this study, however a non-significant tendency with more marginal bone loss in smokers could be seen $(\mathrm{p}=0.058)$. This is in contrast to many other studies showing a relationship between smoking and periodontal disease $(3,7)$. A statistical significant difference cannot be out ruled due to the limited numbers of individuals in the $\mathrm{PD}+$ group in this study.

\section{Strengths}

The study sample was randomly selected from the 
adult population living in the county of Skåne in 2007 $(\mathrm{n}=907$ 702).

The non-response analysis shows a similar distribution in gender and ethnicity compared to the responding group. Regarding age the only difference between the groups were in the oldest age group (8089 years).

The distribution of marginal bone loss in the present study is in accordance with other studies $(4,14$, 21) with a lower degree of non-respondents.

The reading of radiographs is done without knowledge of clinical status of the study sample.

\section{Limitations}

The group of non-respondents was large; this can cause a misinterpretation of the true distribution of marginal bone loss in the population. In the non-responding group answering the questionnaire fewer individuals had a university degree and more were smokers. These are factors considered to be associated with periodontal disease $(15,29)$.

\section{Conclusion}

Eleven percent of the population has experienced generalised periodontal disease, and $53 \%$ of them have a periodontal treatment need defined as 1 or more site with $\mathrm{PPD} \geq 6 \mathrm{~mm}$ and $\mathrm{BoP} \geq 20 \%$. The prevalence and extent of periodontal disease in this study correlates well with other recent studies in Sweden and other countries. An interesting finding is that there were no differences in periodontal disease experience between males and females. This finding is in contrast to the majority of epidemiological studies reporting more periodontal disease in males.

\section{References}

1. Albandar JM, Brunelle JA, Kingman A. Destructive periodontal disease in adults 30 years of age and older in the United States, 1988-1994. J Periodontol 1999; 70:13-29

2. Axelsson P, Lindhe J, Nyström B. On the prevention of caries and periodontal disease. Results of a 15-year longitudinal study in adults. J Clin Periodontol 1991; 18:182-9.

3. Axelsson P, Paulander J, Lindhe J. Relationship between smoking and dental status in 35-, 50-, 65-, and 75-yearold individuals. J Clin Periodontol 1998; 25:297-305.

4. Bahrami G, Isidor F, Kirkevang L, Vaeth M, Wenzel A Marginal bone level in an adult danish population. Oral Health Prev Dent 2006; 4:119-27.

5. Beck J, Garcia R, Heiss G, Vokonas PS, Offenbacher S. Periodontal disease and cardiovascular disease. J Periodontol 1996; 67(Suppl):1123-37.

6. Berglundh T, Donati M. Aspects of adaptive host response in periodontitis. J Clin Periodontol 2005; 32(Suppl 6):87-107
7. Bergström J, Eliasson S. Cigarette smoking and alveolar bonehight in subjects with a high standard of oral hygiene. J Clin Periodontol 1987; 14:466-9.

8. Bourgeois D, Bouchard P, Mattout C. Epidemiology of periodontal status in dentate adults in France, 20022003. J Periodontal Res 2007; 42:219-27.

9. Buhlin K, Hultin M, Norderyd O, Persson L, Pockley AG, Pussinen PJ, Rabe P, Klinge B, Gustafsson A. Periodontal treatment influences risk markers for atherosclerosis in patients with severe periodontitis. Atherosclerosis 2009; 206:518-22.

10. Buhlin K, Hultin M, Norderyd O, Persson L, Pockley AG, Rabe P, Klinge B, Gustafsson A. Risk factors for atherosclerosis in cases with severe periodontitis J Clin Periodontol 2009; 36:541-9.

11. Claffey N, Egelberg J. Clinical indicators of probing attachment loss following initial periodontal treatment in advanced periodontitis patients. J Clin Periodontol $1995 ; 22: 690-6$.

12. Davies I, Karring T, Norderyd O. Advances in the behavioural and public health aspects of periodontitis. Group E consensus report of the fifth European Workshop in Periodontology J Clin Periodontol 2005; 32(Suppl 6):326-7.

13. DeStefano F, Anda RF, Kahn HS, Williamson DF, Russell CM. Dental disease and risk of coronary heart disease and mortality. BMJ 1993; 306:688-91.

14. Edman K, Öhrn K, Holmlund A, Nordström B, Hedin $M$, Hellberg D. Comparison of oral status in an adult population 35-75 year of age in the county of Dalarna, Sweden in 1983 and 2008. Swed dent J 2012; 36:61-70.

15. Eke P, Dye B, Wei L, Thornton-Evans G, Genco R. Prevalence of periodontitis in adults in the united states: 2009 and 2010. J Dent Res 2012; 91: 914-20.

16. Flemmig TF. Periodontitis. Annals of Periodontology 1999; 4:32-8.

17. Holtfreter B, Schwahn C, Biffar R, Kocher T. Epidemiology of periodontal diseases in the Study of Health in Pomerania. J Clin Periodontol 2009; 36:114-23.

18. Holtfreter B, Kocher T, Hoffmann T, Desvarieux M Micheelis W. Prevalence of periodontal disease and treatment demands based on a German dental survey (DMS IV). J Clin Periodontol 2010; 37:211-9.

19. Hugoson A, Sjodin B \& Norderyd O. Trends over zo years, 1973-2003, in the prevalence and severity of periodontal disease. J Clin Periodontol 2008; 35:405-14.

20. Hugoson A, Jordan T. Frequency distribution of individuals aged 20-70 years according to severity of periodontal disease. Community Dent Oral Epidemiol 1982; 10:187-92.

21. Hugoson A, Norderyd O, Slotte C \& Thorstensson $H$. Distribution of periodontal disease in a Swedish adult population 1973, 1983 and $1993 \mathrm{~J} \mathrm{Clin} \mathrm{Periodontol} 1998$. 25:542-8

22. Hugoson A, Norderyd O. Has the prevalence of periodontitis changed during the last 30 years? J Clin Periodontol 2008; 35(Suppl):338-45.

23. Jansson $\mathrm{H}$, Lindholm $\mathrm{E}$, Lindh $\mathrm{C}$, Groop $\mathrm{L} \&$ Bratthall $\mathrm{G}$. Type 2 diabetes and risk for periodontal disease: a role for dental health awareness. J Clin Periodontol 2006; 33:408-14.

24. Klock KS, Haugejorden O. Primary reasons for extraction of permanent teeth in Norway: changes from 1968 to 
1988. Community Dent Oral Epidemiol 1991; 19:336-41.

25. Lundegren N, Axtelius B, Âkerman S. Oral health in the adult population of Skåne, Sweden: a clinical study. Acta Odontol Scand 2012; 6:511-9.

26. Mattila KJ, Nieminen MS, Valtonen VV, Rasi VP, Kesäniemi YA, Syrjälä SL, Jungell PS, Isoluoma M, Hietaniemi K, Jokinen MJ. Association between dental health and acute myocardial infarction BMJ.1989; 298:779-81.

27. Norderyd O, Hugoson A. Risk of severe periodontal disease in a Swedish adult population. A crosssectional study. J Clin Periodontol 1998; 25:1022-8.

28. Norderyd O, Hugoson A, Grusovin G. Risk of severe periodontal disease in a Swedish adult population. A longitudinal study. J Clin Periodontol 1999; 26:608-15.

29. Paulander J, Axelsson P, Lindhe J, Wennström J. Some characteristics of 50/55-year-old individuals with various experience of destructive periodontal disease: a cross-sectional study. Acta Odontol Scand 2004; 62:199-206.

30. Skudutyte-Rysstad R, Eriksen HM, Hansen BF. Trends in periodontal health among 35-year-olds in Oslo, 1973-2003. J Clin Periodontol 2007; 34:867-72.

Corresponding author:

Dr Assa Wahlin,

Department of Periodontology, Faculty of Odontology,

Malmö University,

SE-205 06 Malmö, Sweden

E-mail:asa.wahlin@mah.se 

III 



\section{Impact of Periodontal Disease Experience on Oral Health-Related Quality of Life}

Henrik Jansson, * Åsa Wahlin, ${ }^{*}$ Veronica Johansson, ${ }^{\dagger}$ Sigvard Åkerman, ${ }^{\ddagger}$ Nina Lundegren, ${ }^{\ddagger}$ Per-Erik Isberg, $\$$ and Ola Norderyd*\|

Background: Periodontal research has traditionally focused on the site level, regarding etiology, pathogenesis, and treatment outcome. Recently, some studies have indicated that the presence of periodontal disease is associated with reduced quality of life. The aim of this study is to investigate the impact of periodontal disease experience on the quality of life.

Methods: This cross-sectional study includes 443 individuals. Clinical and radiographic examinations were performed; in conjunction, the oral health-related quality of life of all participants was assessed using the Swedish short-form version of the Oral Health Impact Profile (OHIP-14). Based on marginal bone loss, measured on radiographs, three different groups were identified: participants with loss of supporting bone tissue of less than one third of the root length (BL-), loss of supporting bone tissue of one third or more of the root length in $<30 \%$ of teeth (BL), or loss of supporting bone tissue of one third or more of the root length in $\geq 30 \%$ of teeth (BL+).

Results: The effect of periodontal disease experience on quality of life was considerable. For the BL- group, the mean OHIP-14 score was 3.91 (SD: 5.39). The corresponding mean values were 3.81 (SD: 5.29) for the BL group and 8.47 (SD: 10.38) for the BL+ group. The difference among all groups was statistically significant $(P$ $\leq 0.001$ ). A comparison among the mean OHIP-14 scores in the different groups (BL-, BL, and $\mathrm{BL}+$ ) revealed significant differences in six of seven conceptual domains.

Conclusions: The BL+ individuals experienced reduced quality of life, expressed as the OHIP-14 score, compared with the BL and BL- participants. J Periodontol 2014;85: 438-445.

\section{KEY WORDS}

Alveolar bone loss; health impact assessment; oral health; periodontal disease; periodontitis; quality of life.

* Department of Periodontology, Centre for Oral Health Sciences, Malmö University, Malmö, Sweden.

† Department of Oral Public Health, Centre for Oral Health Sciences, Malmö University. * Department of Oral Diagnostics, Centre for Oral Health Sciences, Malmö University. $\S$ Department of Statistics, Lund University, Lund, Sweden.

Department of Periodontology, Institute for Postgrad Dental Education, Jönköping, Sweden.
$P$ riodontitis is a result of an imbalance between the oral biofilm in the dento-gingival area and the host response. This imbalance results in a loss of supporting periodontal ligaments and alveolar bone. ${ }^{1,2}$ Improved oral health in the adult population in Sweden has resulted in fewer edentulous individuals and concomitantly more individuals with more remaining teeth. $^{3}$ However, despite these improvements, $\approx 10 \%$ of the adult population suffers from severe periodontal disease. ${ }^{4,5}$

Numerous clinical studies have focused on management of the disease in terms of etiology, pathogenesis, efficacy, and outcome of different treatment options. Focus has been on clinical variables such as probing depth (PD) and attachment level, and most studies have used a site perspective rather than an individual perspective. Periodontal disease will, as a result of inflammation and tissue breakdown, produce a wide range of clinical signs and symptoms. These will probably have an impact on the quality of life. ${ }^{6}$ However, few reports reveal the patients' perception of oral health and its influence and contribution to quality of life and overall well-being. ${ }^{7}$ This has led to the development of a number of instruments that aim to measure oral health outcomes, in terms of the impact of changes in oral health on quality of life in population-based studies. 
There are different instruments to measure oral health-related quality of life. One of the most widely used is the Oral Health Impact Profile (OHIP). ${ }^{7}$ The original, long-form instrument measures how oral health affects individuals' quality of life using 49 questions. The short form, consisting of 14 questions (OHIP-14), has emerged as a powerful tool in the assessment of oral health-related quality of life. ${ }^{8}$ Due to its practicality, it has frequently been used in a variety of hospital settings and for a range of dental conditions. ${ }^{9,10}$ Studies have reported the impact of chronic periodontitis on physical comfort or other domains that affect quality of life. ${ }^{11-13}$ There is a lack of large population studies, especially from the Scandinavian countries.

The aim of this study is to investigate the impact of periodontal disease experience on quality of life in a population in the south of Sweden, using the Swedish version of the OHIP-14 questionnaire.

\section{MATERIALS AND METHODS}

\section{Ethical Requirements}

The Medical Ethics Committee of Lund University, Lund, Sweden (ref. no LU 103-2006), approved the study in accordance with the Helsinki Declaration. All study participants gave their signed, informed consent before inclusion in the project.

\section{The Sample}

Skåne, a county in the south of Sweden, had in 2007 a population of 907,702 individuals aged 20 to 89 years old. Of these, 1,000 individuals were randomly selected from the Government's Person Address Register in Sweden and recruited for the Skåne Oral Health Survey. ${ }^{14}$ Of the original sample, 14 individuals had an unknown address, 11 had moved from the region, and nine were deceased, thus leaving 966 individuals as the final sample. Four hundred and fifty-one individuals (219 males, aged 20 to 89 years; mean age: 49.3 years; and 232 females, aged 20 to 88 years; mean age: 48.0 years) agreed to participate in the study.

The study was conducted at the Faculty of Odontology, Malmö University, Sweden, with the purpose of evaluating the oral health need and demand for dental care in the region. Each participant first answered a questionnaire, after which clinical and radiographic examinations were performed.

\section{The Questionnaire}

The questionnaire was divided into different parts concerning patient perception of oral health, oral health care need, pain, use of oral health care, dental materials, and background. The questionnaire consisted of 58 questions. ${ }^{15}$

The OHIP-14 was used to assess the oral healthrelated quality of life. ${ }^{8}$ OHIP-14 is a self-completed questionnaire consisting of 14 items subdivided into seven domains. The OHIP was constructed to measure social impacts of oral problems as a total score index, or in seven dimensions: functional limitation, physical pain, psychologic discomfort, physical disability, psychologic disability, social disability, and handicap. ${ }^{7}$ The seven conceptual domains are derived from the oral health model. ${ }^{6}$ Questions can be answered on a Likert scale: 0 ("never"), 1 ("hardly ever"), 2 ("occasionally"), 3 ("fairly often"), and 4 ("very often"). A Swedish version of the full-length questionnaire (OHIP-49) has been created and assessed regarding reliability and validity. ${ }^{16}$ In the present study, the short-form questions from the Swedish translation and the additive method of calculating scores were used. ${ }^{16,17}$

When performing the statistical analysis, individuals who did not answer all 14 questions were excluded in the analysis of the total OHIP-14 score. However, in the analysis of each question all the given answers were included.

\section{Clinical Periodontal Examination}

The clinical examinations were performed from March 2007 to November 2008 and took place at the Faculty of Odontology at Malmö University and at three Public Dental Service clinics in Skåne, situated in Helsingborg, Kristianstad, and Ystad. The examinations were carried out by eight dentists (NL, Sigvard Åkerman, Lena Widerström, Bengt Götrick, Tore Hallmer, Roland Sundqvist, Bassam Fakhro, and Björn Axtelius) from the Department of Oral Diagnostics at the Faculty of Odontology, Malmö University. The majority of the examinations (90.5\%) were carried out by four of the examiners (NL, SA, Lena Widerström, and Bengt Götrick). The examiners were coordinated regarding the diagnostic criteria through comprehensive written instructions, continual discussions, and clinical case discussions. A standardized examination protocol was used.

One part of the clinical examination was focused on periodontal aspects. From the periodontal examination, the following variables were analyzed.

Number of teeth. Third molars, root remnants, and dental implants were excluded in all measurements.

PD. Only sites with PD $\geq 4 \mathrm{~mm}$ were registered. Measurements were made at four sites for all teeth: mesial, buccal, distal, and lingual. Probing was performed with a calibrated periodontal probe ${ }^{\text {Il }}$ to the nearest millimeter (diameter of the probe tip was 0.5 $\mathrm{mm}$ with $1-\mathrm{mm}$ increments).

Bleeding on probing. Full-mouth bleeding on probing (BOP) was registered in conjunction with periodontal probing. ${ }^{18}$

9 PCP-UNC 157, Hu-Friedy, Chicago, IL. 


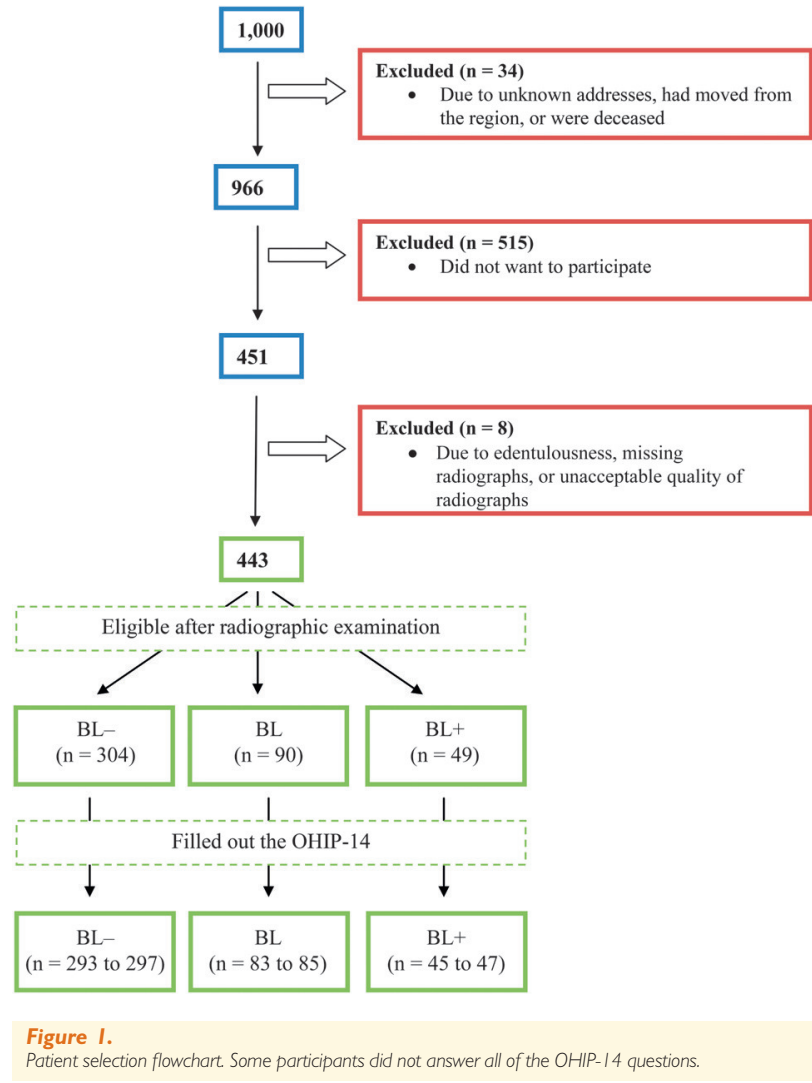

supporting bone less than one third of the root length; 2) $\mathrm{BL}=$ loss of supporting bone tissue one third or more of the root length in $<30 \%$ of teeth; and 3 ) $\mathrm{BL}+=$ loss of supporting bone tissue one third or more of the root length in $\geq 30 \%$ of teeth.

\section{Statistical Analyses}

For the non-response analysis, cross-tabulations were made concerning study non-participation versus age and sex. A logistic regression analysis was performed with response/nonresponse as the dependent variable. First, age and sex were entered into the model as independent variables.

By adding all scores 0 ("never") to 4 ("very often") for each question, the total OHIP-14 score ranges from 0 (no problems at all) to 56 (all problems experienced very often). Thus, a lower score indicates better oral health-related quality of life.

Means and standard deviations were calculated for the OHIP-14. Comparisons among groups were made using Pearson's $\chi^{2}$ test for categorical variables, analysis of variance for numerical variables (one-tailed), and Tukey test for multiple comparisons. A significance level of $5 \%$ was used in all tests. All analyses were made using statistical software.\#

\section{Radiographic Examination}

Digital panoramic and four bitewing radiographs were taken on all participants. Marginal bone loss was analyzed in the radiographs in the manner described by Jansson et al., ${ }^{19}$ by one calibrated examiner (AW). ${ }^{19}$ The examiner was masked and did not have access to any other information except the digital radiographs. Based on the radiographs, eight individuals were excluded: two participants were edentulous, one person was edentulous but with dental implants, radiographs were missing for four individuals, and in one individual the radiographs were of an unacceptable quality. The radiographs were classified into three different categories, according to marginal bone loss: 1) BL- = loss of
Reproducibility of Radiographic Measurements To calculate intra-observer agreement, the assessments of the marginal bone level were repeated in 100 randomly chosen individuals, using $\kappa$ statistics. The $\kappa$ value was 0.8 and the weighted $\kappa$ value was 0.87 .

\section{RESULTS}

\section{Study Population}

After categorization according to marginal bone loss, the eligible number of individuals was reduced to 443 (because of edentulousness, missing radiographs, or unacceptable quality of radiographs): BL$(n=304), \operatorname{BL}(n=90)$, and BL+ $(n=49)$ (Fig. 1).

\# SPSS v.18, IBM, Chicago, IL. 
Table I.

Characteristics (n [\%] or mean \pm SD) of Participants Radiographically Assessed as BL-, BL, and BL+

\begin{tabular}{|c|c|c|c|c|}
\hline Variable & $\mathrm{BL}-$ & $\mathrm{BL}$ & $\mathrm{BL}+$ & P \\
\hline No. of individuals & $304(69)$ & $90(20)$ & $49(11)$ & \\
\hline $\begin{array}{l}\text { Sex } \\
\text { Female } \\
\text { Male }\end{array}$ & $\begin{array}{l}158(52) \\
146(48)\end{array}$ & $\begin{array}{l}50(56) \\
40(44)\end{array}$ & $\begin{array}{l}20(41) \\
29(59)\end{array}$ & NS \\
\hline Age (years) & $42.5 \pm 15.4$ & $59.9 \pm 11.4$ & $64.4 \pm 11.8$ & $\leq 0.001^{*}$ \\
\hline $\begin{array}{l}\text { Education } \\
\text { Primary school } \\
\text { Secondary school } \\
\text { Higher vocational education } \\
\text { University }\end{array}$ & $\begin{array}{r}47(15) \\
99(33) \\
37(12) \\
117(38)\end{array}$ & $\begin{array}{l}30(33) \\
14(16) \\
18(20) \\
24(27)\end{array}$ & $\begin{array}{r}18(37) \\
13(27) \\
9(18) \\
8(16)\end{array}$ & $\leq 0.001$ * \\
\hline Smoking & $49(16)$ & $12(13)$ & $14(29)$ & NS \\
\hline No. of teeth & $26 \pm 3.5$ & $25 \pm 3.5$ & $22 \pm 4.9$ & $\leq 0.001$ \\
\hline $\mathrm{BOP}(\%)$ & $28.1 \pm 19.7$ & $27.9 \pm 19.1$ & $34.8 \pm 27.2$ & NS \\
\hline Sites with PD 4 to $5 \mathrm{~mm}(\%)$ & $5.4 \pm 7.5$ & $8.5 \pm 8.2$ & $21.2 \pm 18.2$ & $\leq 0.001$ \\
\hline Sites with PD $\geq 6$ mm (\%) & $0.2 \pm 0.6$ & $0.6 \pm 1.5$ & $4.3 \pm 5.5$ & $\leq 0.00 \mathrm{I}^{\dagger}$ \\
\hline Individuals with $B O P \geq 20 \%$ and $P D \geq 6 \mathrm{~mm}$ & $34(11)$ & $22(24)$ & $26(53)$ & $\leq 0.001$ \\
\hline
\end{tabular}

NS = not significant.

* Statistically significant difference between the BL- group and the BL and BL+ groups.

$\uparrow$ Statistically significant difference between the BL+ group and the BL- and BL groups.

Of those who did not participate in the clinical examination, $48 \%$ were women, and $52 \%$ were men. The largest non-participating group was men in the age group 30 to 39 years $(n=46)$. Ten percent stated that they were born in a country other than Sweden. Thus, the number of individuals born outside Sweden was lower in the non-participant group than in the participant group. In the non-participating group the percentage of university-educated individuals was $24 \%$. More individuals in the nonparticipating group $(10.9 \%)$ stated that they had a high number of missing teeth (missing $>10$ teeth) than in the group of participants in the clinical study (3.8\%). This difference was significant $(P=0.014)$. There were no significant differences between the non-participants and the participants concerning perceived treatment need and satisfaction with one's teeth. The logistic regression analysis showed that there were significant $(P=0.002)$ differences in participation in the clinical study with regard to age. Individuals in the age group 80 to 89 years were less likely to participate (odds ratio $=2.82$ ). There were no significant differences between the sexes.

\section{Clinical Results}

Table 1 illustrates the distribution of the participants according to number of individuals, sex, age, ed- ucation, smoking habits, number of teeth, and periodontal conditions (BOP, percentage of sites with PD 4 to $5 \mathrm{~mm}$ and PD $\geq 6 \mathrm{~mm}$, and number of individuals with $\mathrm{BOP}>20 \%$ and sites with PD $\geq 6$ $\mathrm{mm}$ ) in each group. Of the BL- participants, 158 (52\%) were female. The corresponding numbers in the BL and BL+ groups were 50 (56\%) and 20 (41\%), respectively. The comparison among $\mathrm{BL}-, \mathrm{BL}$, and $\mathrm{BL}+$ subgroups (Table 1 ) revealed that a significantly lower percentage of BL+ and BL individuals had completed a university education, $17 \%$ and $28 \%$, respectively, versus $39 \%$ for individuals in the $\mathrm{BL}-$ group $(P \leq 0.001)$. There were also significant differences among the $\mathrm{BL}-, \mathrm{BL}$, and $\mathrm{BL}+$ subgroups concerning the number of remaining teeth $(26,25$, and $22 ; P \leq 0.001)$, the percentage of sites with PD 4 to $5 \mathrm{~mm}(5.4 \%, 8.5 \%$, and $21.2 \% ; P \leq 0.001)$, the percentage of sites with PD $\geq 6 \mathrm{~mm}(0.2 \%, 0.6 \%$, and $4.3 \% ; P \leq 0.001)$, and the percentage of individuals with BOP $\geq 20 \%$ and sites with PD $\geq 6 \mathrm{~mm}$ (11\%, 24\%, and 53\%; $P \leq 0.001)$.

\section{Oral Health-Related Quality of Life}

For the BL- individuals, the mean of the total OHIP14 score was 3.91 (SD: 5.39) (Table 2). The corresponding mean values were 3.81 (SD: 5.29) for the BL group and 8.47 (SD: 10.38) for the BL+ 


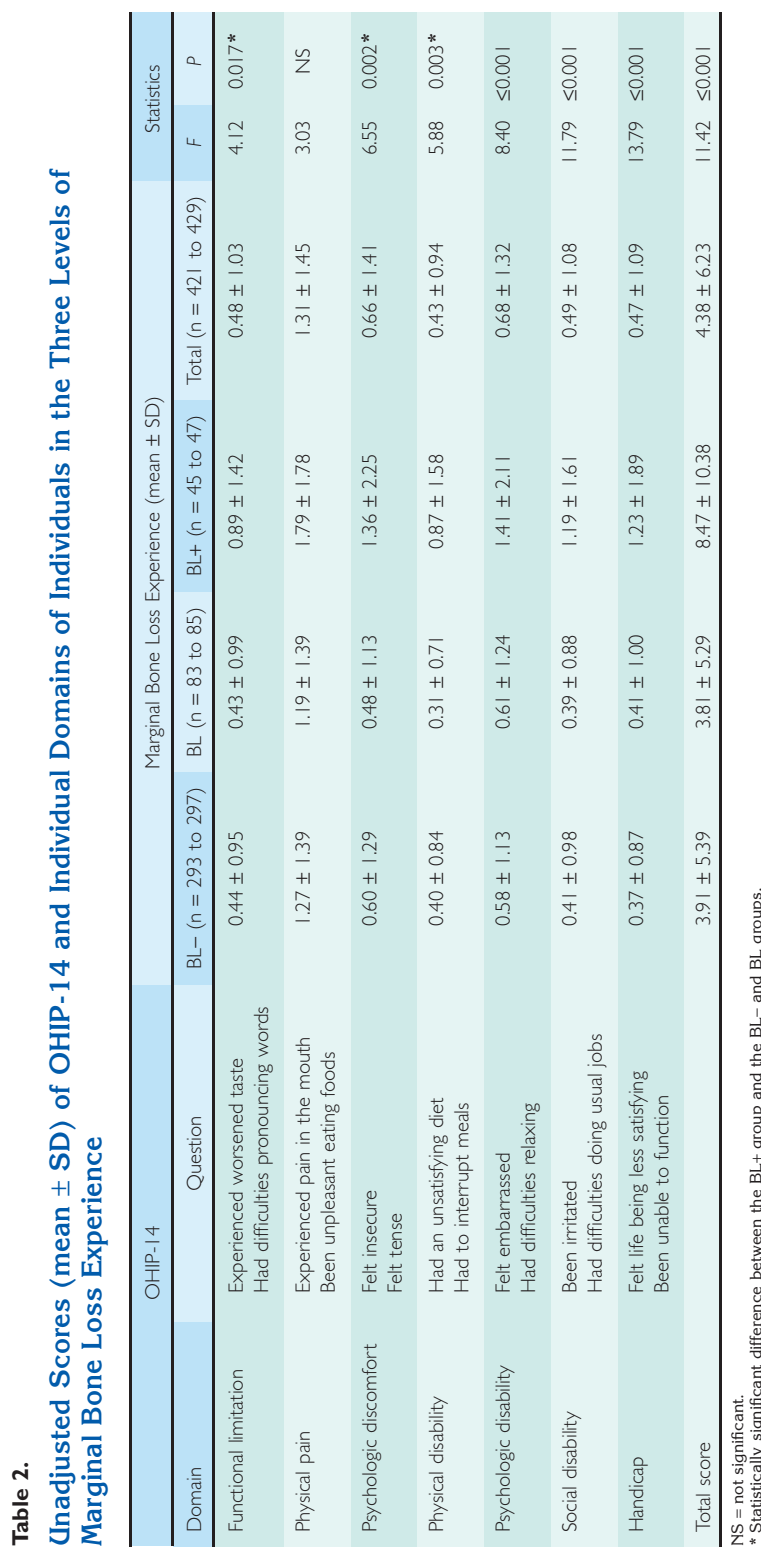

group. The difference among all groups was statistically significant $(P \leq 0.001)$. A comparison among the OHIP-14 scores in the different groups (BL-, BL, and $\mathrm{BL}+$ ), revealed significant differences in six of seven conceptual domains: functional limitation $(P=0.017)$, psychologic discomfort $(P=0.002)$, physical disability $(P=0.003)$, psychologic disability $(P \leq 0.001)$, social disability $(P \leq 0.001)$, and handicap $(P \leq 0.001)$.

A multiple regression model was formulated by a forward stepwise analysis having the total OHIP-14 score as the dependent variable (Table 3). When including all individuals, the independent variables: 1) number of remaining teeth; 2) smoking; and 3) number of individuals with periodontal treatment need, expressed as having at least one PD $\geq 6 \mathrm{~mm}$ and at the same time full-mouth BOP $\geq 20 \%$, had a statistically significant influence on the total OHIP-14 score. However, the coefficient of determination for this particular model was only 0.078 .

\section{DISCUSSION}

The key finding in the present study is that the BL+ individuals experienced a worse quality of life compared with the BL- individuals. Today there is growing support for the existence of a correlation between the degree of periodontal disease and oral health-related quality of life. However, many studies have been conducted on children and adolescents, who have a low prevalence of marginal bone loss. This is the first large cross-sectional study ( $\mathrm{n}=443$ individuals), and the study population is a random sample of the adult (ages 20 to 79 years) population in a larger geographic area in the southern part of Sweden (Region Skåne, $\mathrm{n}=$ 907,702). The result from the present study is in agreement with previous studies, which have found that loss of clinical attachment may have an impact on quality of life. ${ }^{12,13,20}$ Furthermore, a study investigating 
Table 3.

Multiple Regression Analysis $(n=421)$ in Which the Dependent Variable Is the Total OHIP-14 Score

\begin{tabular}{|c|c|c|c|c|}
\hline \multirow[b]{2}{*}{ Variable } & \multirow[b]{2}{*}{ Coefficient } & \multicolumn{2}{|c|}{$95 \%$ Confidence Interval } & \multirow[b]{2}{*}{$P$} \\
\hline & & Lower Bound & Upper Bound & \\
\hline Constant & 13.898 & & & \\
\hline Age (years) & -0.035 & -0.079 & 0.010 & 0.13 \\
\hline Smoking & 1.925 & 0.285 & 3.564 & 0.022 \\
\hline No. of teeth & -0.394 & -0.584 & -0.203 & $<0.00$ । \\
\hline $\mathrm{BOP} \geq 20 \%$ and $\mathrm{PD} \geq 6 \mathrm{~mm}$ & 1.829 & 0.257 & 3.401 & 0.023 \\
\hline \multicolumn{5}{|l|}{ Education } \\
\hline Secondary school & 0.305 & -1.583 & 2.193 & 0.751 \\
\hline Higher vocational education & -1.249 & -3.250 & 0.753 & 0.221 \\
\hline University & -0.368 & -2.114 & 1.378 & 0.679 \\
\hline
\end{tabular}

the impact of periodontal disease on quality of life in individuals attending a private periodontal practice found that a broad range of physical, social, and psychologic aspects of quality of life were affected by periodontal disease. ${ }^{11}$ In contrast, Biazevic et al. ${ }^{21}$ did not find that the prevalence of periodontal disease had any impact on the quality of life. However, their finding can perhaps be explained by the fact that the study population were adolescents and had a low prevalence of periodontal disease.

Regarding experience of physical pain due to the oral condition, no significant differences could be detected in the present study. This is in contrast to Saito et al., ${ }^{20}$ who reported a significant difference in experience of physical pain between individuals with or without periodontal disease at baseline. The difference in findings may, perhaps, be due to different oral health-related quality of life measurements being used, or to cultural differences among individuals in the study samples.

In the present study, a statistically significant difference is found between the BL+ and BL-groups regarding education level. This is in accordance with a recent systematic review and meta-analysis, which found that a low education level is associated with an increased risk of periodontitis. ${ }^{22}$

There was no significant difference among the periodontal groups regarding smoking. However, smoking was significantly related to a decrease in oral health-related quality of life. Associations between smoking and reduced oral health-related quality of life have been found in multivariate analyses in other studies. ${ }^{23-29}$ However, there is a lack of knowledge as to what the association means. Tomar et al. ${ }^{25}$ proposed that cigarette smoking may be ei- ther an independent risk factor for reduced oral health-related quality of life or may serve as a marker for an underlying but unidentified factor. The nature of the association between smoking and reduced oral health-related quality of life needs to be investigated in future studies.

The body of evidence suggesting that periodontal therapy, non-surgical and/or surgical, is effective in establishing healthy periodontal conditions is convincing and has been well established in numerous clinical studies. ${ }^{30-33}$ However, most studies focus primarily on clinical outcomes, such as improvements in gingival inflammation, probing pocket reduction, and gain in clinical attachment level. In recent years, the study of patient-centered treatment outcome has been advocated, rather than site-centered outcome. ${ }^{34,35}$

A weakness of the present study is the low response rate, $46 \%$. Presumably, the participation rate would be related to how recent the individual's latest checkup was, general health, the need for a second opinion on dental status, and the oral treatment need. The shortage of individuals belonging to the oldest age group ( 80 to 89 year olds) among the examined participants may make the results for this particular age group uncertain. This age group is, however, well represented in the non-response questionnaire.

Another weakness of the present study may be that the outcome variable used to assess oral health-related quality of life, the short-form OHIP instrument, suffers from certain limitations such as a floor effect, i.e., a majority of scores accumulate at the bottom of the scale. ${ }^{36}$ The highest mean OHIP14 score found in this study was 8.47 for the BL+ group. In relation to the range of the OHIP-14, from 
0 (indicating excellent oral health-related quality of life) to a possible 56, the mean is low. This may indicate that the patients with severe periodontal disease still experience their oral health-related quality of life as very good; however, it can also be an indication that the OHIP-14 does not fully capture the impact of periodontitis in relation to quality of life. However, although limited in certain aspects, the OHIP-14 has been found to discriminate between groups, for example, between persons with and without problems chewing, wearing dentures, having dry mouth, and with or without need for endodontic treatment. ${ }^{36,37}$ In this study, the OHIP-14 also discriminates among the different periodontal condition groups.

Further, the multiple regression analysis had a very low explanatory power, $R^{2}=0.078$. Thus, the independent variables included in the analysis did not constitute factors highly affecting the oral healthrelated quality of life. Further studies are needed to investigate what affects the quality of life in patients with periodontal disease.

One strength of the present study is that the prevalence of periodontal disease was largely in line with other studies from Sweden. 4,38

\section{CONCLUSIONS}

Individuals with severe marginal bone loss experienced worse quality of life compared with individuals with no/minor marginal bone loss. The result from the present study emphasizes the need for prevention and early treatment of periodontal disease, as severe periodontal bone loss has a negative effect on the individual's quality of life. There is a need for studies exploring whether periodontal treatment can improve quality of life in individuals with severe periodontal disease. Such studies could lead to a better understanding of patient demands and give the therapist the possibility to better tailor the treatment.

\section{ACKNOWLEDGMENTS}

This study has been financially supported by a research grant provided by the Regional Board of Dental Public Health in the county of Skåne. The authors would like to thank the following persons who performed the clinical examinations: Lena Widerström, Bengt Götrick, Tore Hallmer, Roland Sundqvist, Bassam Fakhro, and Björn Axtelius, all from the Department of Oral Diagnostics, Centre for Oral Health Sciences, Malmö University, Malmö, Sweden. The authors report no conflicts of interest related to this study.

\section{REFERENCES}

1. Berglundh T, Donati $M$. Aspects of adaptive host response in periodontitis. J Clin Periodontol 2005;32 (Suppl. 6):87-107.
2. Flemmig TF. Periodontitis. Ann Periodontol 1999;4: 32-38.

3. Hugoson A, Norderyd O, Slotte C, Thorstensson H. Distribution of periodontal disease in a Swedish adult population 1973, 1983 and 1993. J Clin Periodontol 1998;25:542-548.

4. Hugoson A, Sjödin B, Norderyd O. Trends over 30 years, 1973-2003, in the prevalence and severity of periodontal disease. J Clin Periodontol 2008;35:405414.

5. Wahlin A, Jansson H, Klinge B, Lundegren N, Åkerman $\mathrm{S}$, Norderyd O. Marginal bone loss in the adult population in the county of Skåne, Sweden. Swed Dent $J$ 2013;37:39-47.

6. Locker D. Measuring oral health: A conceptual framework. Community Dent Health 1988;5:3-18.

7. Slade GD, Spencer AJ. Development and evaluation of the Oral Health Impact Profile. Community Dent Health 1994;11:3-11.

8. Slade GD. Derivation and validation of a short-form oral health impact profile. Community Dent Oral Epidemiol 1997;25:284-290

9. McGrath C, Comfort MB, Lo EC, Luo Y. Can third molar surgery improve quality of life? A 6-month cohort study. J Oral Maxillofac Surg 2003;61:759-763, discussion 764-765.

10. Locker D, Matear D, Stephens M, Lawrence H, Payne B. Comparison of the GOHAI and OHIP-14 as measures of the oral health-related quality of life of the elderly. Community Dent Oral Epidemiol 2001;29:373-381.

11. Needleman I, McGrath C, Floyd P, Biddle A. Impact of oral health on the life quality of periodontal patients. $J$ Clin Periodontol 2004;31:454-457.

12. Ng SK, Leung WK. Oral health-related quality of life and periodontal status. Community Dent Oral Epidemiol 2006;34:114-122.

13. Cunha-Cruz J, Hujoel PP, Kressin NR. Oral healthrelated quality of life of periodontal patients. J Periodontal Res 2007;42:169-176.

14. Lundegren N, Axtelius B, Akerman S. Oral health in the adult population of Skåne, Sweden: A clinical study. Acta Odontol Scand 2012;70:511-519.

15. Lundegren N, Axtelius B, Akerman S. Self perceived oral health, oral treatment need and the use of oral health care of the adult population in Skåne, Sweden. Swed Dent J 2011;35:89-98.

16. Larsson P, List T, Lundström I, Marcusson A, Ohrbach R. Reliability and validity of a Swedish version of the Oral Health Impact Profile (OHIP-S). Acta Odontol Scand 2004;62:147-152.

17. Allen PF, Locker D. Do item weights matter? An assessment using the oral health impact profile. Community Dent Health 1997;14:133-138.

18. Mühlemann HR, Son S. Gingival sulcus bleeding - A leading symptom in initial gingivitis. Helv Odontol Acta 1971;15:107-113.

19. Jansson H, Lindholm E, Lindh C, Groop L, Bratthall G. Type 2 diabetes and risk for periodontal disease: A role for dental health awareness. J Clin Periodontol 2006; 33:408-414.

20. Saito A, Hosaka Y, Kikuchi M, et al. Effect of initial periodontal therapy on oral health-related quality of life in patients with periodontitis in Japan. J Periodontol 2010;81:1001-1009.

21. Biazevic MG, Rissotto RR, Michel-Crosato E, Mendes LA, Mendes MO. Relationship between oral health and 
its impact on quality of life among adolescents. Braz Oral Res 2008;22:36-42.

22. Boillot A, El Halabi B, Batty GD, Rangé H, Czernichow $\mathrm{S}$, Bouchard P. Education as a predictor of chronic periodontitis: A systematic review with meta-analysis population-based studies. PLoS ONE 2011:6:e21508.

23. Maida CA, Marcus M, Spolsky VW, Wang Y, Liu H Socio-behavioral predictors of self-reported oral health-related quality of life. Qual Life Res 2013;22: 559-566.

24. Crocombe LA, Broadbent JM, Thomson WM, Brennan DS, Poulton R. Impact of dental visiting trajectory patterns on clinical oral health and oral health-related quality of life. J Public Health Dent 2012;72:36-44.

25. Tomar SL, Pereyra M, Metsch LR. Oral health-related quality of life among low-income adults living with HIV. J Public Health Dent 2011;71:241-247.

26. Mbawalla HS, Masalu JR, Astrøm AN. Socio-demographic and behavioural correlates of oral hygiene status and oral health related quality of life, the Limpopo-Arusha school health project (LASH): A cross-sectional study. BMC Pediatr 2010;10:87.

27. Mulligan R, Seirawan H, Alves ME, et al. Oral healthrelated quality of life among HIV-infected and at-risk women. Community Dent Oral Epidemiol 2008;36: 549-557.

28. Thomson WM, Lawrence HP, Broadbent JM, Poulton R. The impact of xerostomia on oral-health-related quality of life among younger adults. Health Qual Life Outcomes 2006;4:86

29. Morin NM, Dye BA, Hooper TI. Influence of cigarette smoking on the overall perception of dental health among adults aged $20-79$ years, United States, 1988 1994. Public Health Rep 2005;120:124-132.

30. Axelsson P, Lindhe J. The significance of maintenance care in the treatment of periodontal disease. J Clin Periodontol 1981;8:281-294.

31. Axelsson P, Nyström B, Lindhe J. The long-term effect of a plaque control program on tooth mortality, caries and periodontal disease in adults. Results after 30 years of maintenance. J Clin Periodontol 2004:31:749-757.

32. Lindhe J, Nyman S. The effect of plaque control and surgical pocket elimination on the establishment and maintenance of periodontal health. A longitudinal study of periodontal therapy in cases of advanced disease. J Clin Periodontol 1975;2:67-79.

33. Nyman S, Lindhe J, Rosling B. Periodontal surgery in plaque-infected dentitions. J Clin Periodontol 1977;4: 240-249.

34. Davies I, Karring T, Norderyd O; European Workshop in Periodontology group E. Advances in the behavioural and public health aspects of periodontitis. Group E consensus report of the fifth European Workshop in Periodontology. J Clin Periodontol 2005;32(Suppl. 6): 326-327.

35. Heitz-Mayfield LJ, Trombelli L, Heitz F, Needleman I, Moles D. A systematic review of the effect of surgical debridement vs non-surgical debridement for the treatment of chronic periodontitis. J Clin Periodontol 2002; 29(Suppl. 3):92-102, discussion 160-162.

36. Locker D, Allen PF. Developing short-form measures of oral health-related quality of life. J Public Health Dent 2002;62:13-20.

37. Liu P, McGrath C, Cheung GS. Quality of life and psychological well-being among endodontic patients: A case-control study. Aust Dent J 2012;57:493-497.

38. Edman K, Öhrn K, Holmlund A, Nordström B, Hedin M, Hellberg D. Comparison of oral status in an adult population 35-75 year of age in the county of Dalarna, Sweden in 1983 and 2008. Swed Dent J2012;36:61-70.

Correspondence: Assoc. Prof. Henrik Jansson, Department of Periodontology, Faculty of Odontology, Malmö University, SE-205 06 Malmö, Sweden. Fax: +46 40 6658405; e-mail: henrik.jansson@mah.se.

Submitted March 19, 2013; accepted for publication May $10,2013$. 


ISBN 978-9I-7 IO4-726-7 (print)

ISBN 978-9I-7 IO4-727-4 (pdf)

MALMÖ UNIVERSITY 20506 MALMÖ, SWEDEN WWW.MAH.SE 